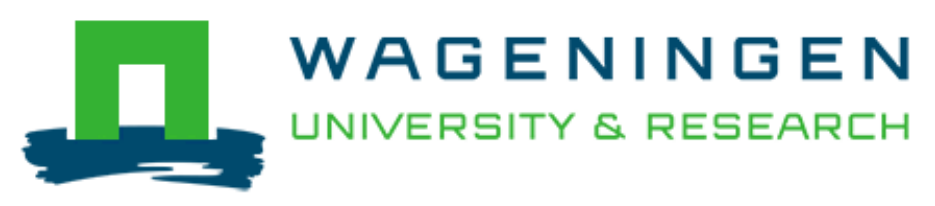

Cognitive performance: a cross-sectional study on serum vitamin D and its interplay with glucose homeostasis in Dutch older adults

Brouwer-Brolsma, E. M., Dhonukshe-Rutten, R. A. M., van Wijngaarden, J. P., van der Zwaluw, N. L., in 't Veld, P. H., Wins, S., ... de Groot, C. P. G. M.

This is a "Post-Print" accepted manuscript, which has been published in "Journal of the American Medical Directors Association"

This version is distributed under a non-commercial no derivatives Creative Commons (c) (1) $\Theta \Theta$

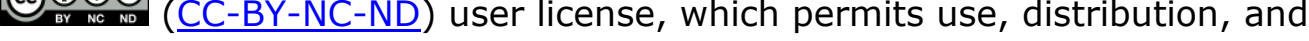
reproduction in any medium, provided the original work is properly cited and not used for commercial purposes. Further, the restriction applies that if you remix, transform, or build upon the material, you may not distribute the modified material.

Please cite this publication as follows:

Brouwer-Brolsma, E. M., Dhonukshe-Rutten, R. A. M., van Wijngaarden, J. P., van der Zwaluw, N. L., in 't Veld, P. H., Wins, S., ... de Groot, C. P. G. M. (2015). Cognitive performance: a cross-sectional study on serum vitamin $D$ and its interplay with glucose homeostasis in Dutch older adults. Journal of the American Medical Directors Association, 16(7), 621-627. https://doi.org/10.1016/j.jamda.2015.02.013 


\section{Cognitive performance: a cross-sectional study on serum vitamin D and its interplay with glucose homeostasis in Dutch older adults.}

EM Brouwer-Brolsma $\mathrm{PhD}^{1}$, RAM Dhonukshe-Rutten $\mathrm{PhD}^{1}, \mathrm{JP}$ van Wijngaarden $\mathrm{PhD}^{1}, \mathrm{NL}$ van de Zwaluw $\mathrm{PhD}^{1}, \mathrm{PH}$ in 't Veld $\mathrm{MSc}^{1}, \mathrm{~S}$ Wins $\mathrm{MSc}^{1}, \mathrm{KMA}$ Swart $\mathrm{MSc}^{2}$, AW Enneman $\mathrm{PhD}^{3}, \mathrm{AC}$ Ham $\mathrm{MSc}^{3}, \mathrm{SC}$ van Dijk $\mathrm{MD}^{3}, \mathrm{NM}$ van Schoor $\mathrm{PhD}^{2}, \mathrm{~N}$ van der Velde $\mathrm{PhD}^{3,4}, \mathrm{AG}$ Uitterlinden $\mathrm{PhD}^{3}, \mathrm{P}$ Lips $\mathrm{PhD}^{8}$, RPC Kessels $\mathrm{PhD}^{5,6,7}$, WT Steegenga $\mathrm{PhD}^{1}$, EJM Feskens $\mathrm{PhD}^{1}, \mathrm{LCPGM}$ de Groot PhD ${ }^{1}$

${ }^{1}$ Division of Human Nutrition, Wageningen University, P.O. Box 8129, 6700 EV Wageningen, the Netherlands

${ }^{2}$ Department of Epidemiology and Biostatistics and the EMGO Institute for Health and Care Research, VU University Medical Center, Van der Boechorststraat 7, 1081 BT Amsterdam, the Netherlands

${ }^{3}$ Department of Internal Medicine, Erasmus University Medical Center, P.O. Box 2040, 3000 CA Rotterdam, the Netherlands

4 Department of Internal Medicine, Section of Geriatrics, Academic Medical Center, University of Amsterdam, Meibergdreef 9, 1105 AZ Amsterdam, The Netherlands

${ }^{5}$ Department of Geriatrics, Radboud University Medical Center, P.O. box 9101, 6500 HB Nijmegen, the Netherlands

${ }^{6}$ Department of Medical Psychology, Radboud University Medical Center, P.O. box 9101, 6500 HB Nijmegen, the Netherlands

${ }^{7}$ Donders Institute for Brain, Cognition and Behavior, Radboud University Nijmegen, P.O. box 9104, 6500 HE Nijmegen, the Netherlands

8 Department of Internal Medicine, Endocrine Section, VU University Medical Center. P.O.Box 7057, 1007 MB Amsterdam, The Netherlands 
1 Cognitive performance: a cross-sectional study on serum vitamin D and 2 its interplay with glucose homeostasis in Dutch older adults. 
Abstract

4

5 Objectives: First of all, the association between serum 25-hydroxyvitamin D

$6(25(\mathrm{OH}) \mathrm{D})$ and cognitive performance was examined. Secondly, we assessed

7 whether there was evidence for an interplay between 25(OH)D and glucose

8 homeostasis in the association with cognitive performance.

9

Design, Setting and Participants: Associations were studied using cross-

11 sectional data of 776 (3 domains) up to 2722 (1 domain) Dutch community12 dwelling older adults, aged $\geq 65$ years.

14 Measurements: Serum 25(OH)D, plasma glucose and insulin concentrations 15 were obtained. Cognitive performance was assessed with an extensive 16 cognitive test battery. Prevalence Ratio's (PRs) were calculated to quantify 17 the association between 25(OH)D and cognition; poor performance was defined as the worst $10 \%$ of the distribution of the cognitive scores.

Results: The overall median MMSE score was 29 (IQR 28-30). Higher serum

21 25(OH)D was associated with better attention and working memory, PR 0.50 $22(95 \% \mathrm{Cl} 0.29-0.84)$ for the third serum 25(OH)D tertile, indicating a 50\% lower 23 probability of being a poor performer than participants in the lowest tertile. 24 Beneficial trends were shown for 25(OH)D with executive function and 25 episodic memory. Serum 25(OH)D was not associated with plasma glucose or 
26 insulin. Plasma insulin only modified the association between serum 25(OH)D

27 and executive function ( $P$ for interaction: 0.001), suggesting that the 28 improvement in executive function with high $25(\mathrm{OH}) \mathrm{D}$ concentrations is 29 stronger in participant with high plasma insulin concentrations compared to 30 those with low plasma insulin concentrations.

31

32 Conclusion: Higher 25(OH)D concentrations significantly associated with 33 better attention and working memory performance. This study does not 34 demonstrate an interplay between serum 25(OH)D and glucose homeostasis 35 in the association with cognitive performance.

36

37 Keywords: Vitamin D, plasma glucose, plasma insulin, type 2 diabetes, 38 cognition, dementia. 


\section{Introduction}

Aging is a generally known key risk factor for dementia. However, the exact underlying pathophysiological mechanisms still need to be unraveled. Nutritional factors may play a role; vitamin $D$ is one of the nutrients under study ${ }^{1}$.

Several studies have provided biological evidence for a role of vitamin D in cognitive performance (reviewed in ${ }^{2-5}$ ). The discovery of vitamin $\mathrm{D}$ receptors and $1-\mathrm{OH}$-ase, the enzyme that catalyses the conversion of the biological inactive form of vitamin $D(25(\mathrm{OH}) \mathrm{D})$ in the biological active form 1,25 dihydroxyvitamin $\mathrm{D}\left(1,25(\mathrm{OH})_{2} \mathrm{D}\right)$, in brain tissue are probably the two most clear findings supporting a potential vitamin D effect. Next to that, treatment with $1,25(\mathrm{OH})_{2} \mathrm{D}$ has been shown to stimulate amongst others neurotrophin synthesis, choline acetyltransferase activity, and amyloid clearance (reviewed in ${ }^{2-4}$ ). Finally, besides these direct pathways between vitamin $\mathrm{D}$ and cognitive performance, one might also think of indirect pathways. For instance, vitamin D deficiency has been associated with glucose intolerance ${ }^{6}$. Glucose intolerance on its turn has been related to both vascular damage and cognitive decline ${ }^{7}$. Accordingly, it may be that the potential favourable effect of vitamin $\mathrm{D}$ on cognitive performance can be partially explained by its beneficial effect on glucose tolerance. It may also be that glucose tolerance biologically interacts with vitamin $\mathrm{D}$. Therefore, it may be that the potential association between vitamin D and cognitive function appears to be stronger 
62 in persons with glucose intolerance than in their glucose tolerant counterparts.

63 These possible pathways, however, have only been examined in a few 64 studies $^{8-12}$.

65

66 So far, results from observational studies ${ }^{1,8-11,13-18}$ exploring the association 67 between serum 25(OH)D and cognition in humans have been equivocal. Four 68 studies adjusted their final analyses for a marker of glucose homeostasis ${ }^{8-11}$;

69 one suggests a modest role for type 2 diabetes ${ }^{10}$. Unfortunately, more 70 detailed studies examining the influence of glucose homeostasis in the 71 association between serum 25(OH)D and cognitive performance are lacking.

72

73 Therefore, we studied the association between serum 25(OH)D and domain74 specific cognitive performance in Dutch older adults aged $\geq 65$ years, with a 75 specific interest for the potential mediating and modifying role of glucose 76 homeostasis. 
Methods

\section{Participants}

This cross-sectional study was performed using baseline data of the BPROOF study; a randomized, double blind, placebo-controlled trial designed to assess the effect of daily oral supplementation of vitamin $B_{12}(500 \mu \mathrm{g})$ and folic acid $(400 \mu \mathrm{g})$ on fractures in mildly hyperhomocysteinemic older adults $\geq 65$ years. This large multi-centre project was conducted in The Netherlands by a consortium from Erasmus MC (EMC, Rotterdam), VU University Medical Center (VUmc, Amsterdam) and Wageningen University (WU, Wageningen), with the latter acting as coordinator. Recruitment took place from August 2008 until March 2011. Participants were largely recruited via the registries of municipalities in the area of the research centres, by contacting all inhabitants aged $\geq 65$ years by mail. In addition, participants were recruited by means of information brochures and meetings that were provided to inhabitants of elderly homes in the area of Rotterdam, Amsterdam and Wageningen. Finally, we also contacted elderly people who had participated in previous studies of the research centres. Participants with homocysteine concentrations $<12 \mu \mathrm{mol} / \mathrm{L}$ or $>50 \mu \mathrm{mol} / \mathrm{L}$, and creatinine concentrations $>150 \mu \mathrm{mol} / \mathrm{L}$ were excluded from participation of the study. Further details on this study can be obtained from the design paper ${ }^{19}$. The Medical Ethics Committee of Wageningen UR approved the study protocol and the Medical Ethics Committees of VUmc and Erasmus MC confirmed local feasibility. All 
participants gave written informed consent. For the current analyses, only

101 data of participants with serum 25(OH)D measurements have been used $102(\mathrm{n}=2857)$ (supplementary Figure I).

103

104 Cognitive performance

105 Cognitive performance was assessed according to a standard protocol, by a 106 well-trained staff. The Mini-Mental State Examination (MMSE) was 107 administered to assess overall cognitive status ${ }^{20}$. An extensive 108 neuropsychological test battery covered four cognitive domains: attention and 109 working memory $(n=787)$, executive functioning $(n=776)$, information 110 processing speed $(n=797)$ and episodic memory $(n=2722)$.

111 The Rey Auditory Verbal Learning Test (RAVLT) was used to measure 112 immediate and delayed recall, as well as recognition for word lists, as indices 113 of episodic memory ${ }^{21}$. RAVLT decayed recall was calculated as the number 114 of words recalled approximately 15 minutes after the fifth session of the 115 RAVLT minus the number of words recalled at the fifth session of the RAVLT. 116 The Digit Span forward and backward from the Wechsler Adult Intelligence 117 Test (WAIS-III) measures attention and working memory ${ }^{22}$. Trail Making Test 118 (TMT) part A measured information processing speed, and part B assessed 119 concept-shifting interference as part of executive functioning ${ }^{23}$. Stroop Color120 Word Test measured selective attention and inhibition as part of executive 121 functioning ${ }^{24}$. To control for the effect of motor speed on TMT and Stroop 122 performance, we calculated interference measures, specifically TMT-ratio 
123 (TMT B/TMT A) and Stroop part 3 (Time needed for Stroop part 3 - [mean 124 time needed for Stroop part 1 and 2]). The Symbol Digit Modalities Test 125 (SDMT) measures information processing speed ${ }^{25}$. Letter Fluency - using 126 three letters - measured response generation as part of executive function ${ }^{26}$.

127 The letter fluency score was composed of the sum score of the three letters.

128 To compare the results of the individual cognitive tests and to limit the number 129 of dependent variables, raw test scores were clustered into compound scores 130 for the four neuropsychological domains. Data of baseline measurements 131 were used as norm data to create individual Z-scores $(Z$-score $=($ score test 132 mean baseline)/SD baseline) and the following domains in formula form were 133 created: Episodic memory $=\left(Z_{\text {RAVLT total immediate recall }}+Z_{\text {RAVLT decayed recall }}+Z\right.$ 134 RAVLT recognition $) / 3$, Attention and working memory $=(Z$ Digit Span forward $+Z$ Digit Span 135 backward $) / 2$, Information processing speed $=(-Z$ Stroop mean I and II $+-Z$ Trail making test 136 part $\mathrm{A}+\mathrm{Z}$ symbol Digit Modalities Test $) / 3$, Executive functioning $=(-Z$ stroop interference $+-Z$ 137 Trail making ratio $+Z$ verbal Fluency)/3. Cognitive performance was dichotomized: a 138 participant belonging to the worst $10 \%$ of cognitive performers was defined as 139 being a poor performer. The other $90 \%$ of the population was defined as 140 'normal' performer ${ }^{27}$.

142 Biochemical analyses

143 Blood samples were drawn in the morning when the participants were fasted 144 or had consumed a restricted breakfast. Samples were stored at $-80{ }^{\circ} \mathrm{C}$ until 145 determination. Serum 25(OH)D was measured by isotope dilution - online 
solid phase extraction liquid chromatography - tandem mass spectrometry (ID-XLC-MS/MS) ${ }^{28}$. Plasma glucose concentrations were analysed using a hexokinase method (Gluco-quant, Roche Diagnostics). Insulin levels were determined using an immunometric assay (ADVIA Centaur immunoassay system, Siemens Medical Solutions Diagnostics). Creatinine concentration was measured using the enzymatic colorimetric Roche CREA plus assay.

\section{Covariates}

Height was measured at baseline with a stadiometer to the nearest $0.1 \mathrm{~cm}$. Weight was measured to the nearest $0.5 \mathrm{~kg}$ with a calibrated analogues scale. Body Mass Index (BMI) was calculated as weight/height ${ }^{2}$. Data on education level (primary, secondary or higher education), smoking status (non-smoker, current smoker, former smoker), physical activity (kcal/day) ${ }^{29}$, alcohol consumption (light, moderate, excessive) ${ }^{30}$, history of falling in the 12 months prior to baseline, and disease history were collected by means of questionnaires. The physical performance score was calculated by summing the scores of three individual tests (0-12 points), specifically the time taken to walk six meters including a $180^{\circ}$ turn (walking test), time taken to rise five times from a chair without using the hands as fast as possible (chair stand test), and the ability to perform the tandem stand for ten seconds (tandem stand). The 15-item Geriatric Depression Scale (GDS) was used as a screening tool for depression. Scores $\geq 5$ are indicative of a depressive episode ${ }^{31}$. Season was based on the month of blood sampling. Season of 
169 blood collection was dichotomized into summer (June-November) and winter

170 (December-May). Covariate selection was based on the current scientific

171 literature. Specifically, a variable was considered potentially relevant for the

172 associations under study when literature indicated that the variable might be

173 associated with serum 25(OH)D status, might affect cognitive performance,

174 was not considered a mediating factor in the causal path or a surrogate

175 marker for the exposure.

176

177 Statistical Analyses

178 Participant characteristics are reported as mean with standard deviation (SD),

179 or percentages. Medians with interquartile range (IQR) were used to report 180 skewed variables.

181 Cox proportional hazards analysis with robust error variance was conducted

182 to calculate Prevalence Ratio's (PRs) for domain-specific cognitive 183 performance per serum 25(OH)D tertile, using the lowest tertile as the 184 reference group. By assigning a constant risk period to all participants in the 185 study, the obtained hazard ratio can be considered as a prevalence ratio (PR)

$186 \quad 32$. This PR corresponds to the probability of being defined as a poor cognitive

187 performer in participants with moderate or high serum 25(OH)D 188 concentrations, compared to participants with low serum 25(OH)D

189 concentrations. Analyses were adjusted for age, sex (model 1), BMI, 190 education, smoking, alcohol consumption, habitual physical activity and 191 season of blood sampling (model 2). 
192 The dose-response of the association between serum 25(OH)D with plasma 193 glucose and plasma insulin was explored by restricted cubic spline regression, 194 and multiple linear regression analyses. Plasma glucose and plasma insulin 195 were not normally distributed and therefore logarithmically transformed. All 196 analyses were adjusted for age, sex (model 1), BMI, education, smoking, 197 alcohol consumption, habitual physical activity and season of blood sampling 198 (model 2).

199 Cox proportional hazards analysis was used to evaluate the associations of 200 plasma glucose and plasma insulin with domain-specific cognitive 201 performance; results are presented per 0.1 and 5 unit increment in plasma 202 glucose and plasma insulin, respectively. Analyses were adjusted for age, sex 203 (model 1), BMI, education, smoking, alcohol consumption and habitual 204 physical activity (model 2) and depression.

205 Mediation of the association between serum 25(OH)D and cognitive 206 performance by glucose homeostasis was examined by studying the 207 association 1) between serum 25(OH)D and glucose homeostasis, 2) between 208 glucose homeostasis and domain-specific cognitive performance and 3) by 209 adding plasma glucose and plasma insulin, independently, to fully adjusted 210 Cox proportional hazards models that explored the associations between 211 serum 25(OH)D and domain-specific cognitive performance. Moreover, the 212 interaction between serum 25(OH)D and glucose homeostasis in its 213 association with cognitive performance was tested. In case of significant 214 findings, data was also presented stratified. 
215 A P-value of $<0.05$ was used to determine statistical significance. Analyses

216 were performed using the statistical package SAS, version 9.1 (SAS Institute 217 Inc., Cary, NC, USA). Spline regression analyses were performed using R 218 version 2.15 


\section{Results}

220 Table I shows the population characteristics. Participants of the subsample 221 who participated in more extensive cognitive performance assessment were 222 on average $72.5 \pm 5.7$ years of age and had a median MMSE score of 29 (IQR: 223 28-30). Mean serum 25(OH)D concentration was $60 \pm 26 \mathrm{nmol} / \mathrm{L}$. Thirty-seven 224 percent of the participants had serum 25(OH)D concentrations below the 225 recommended concentration of $50 \mathrm{nmol} / \mathrm{L}^{33}$. Mean plasma glucose level was $2265.8 \pm 1.4 \mathrm{mmol} / \mathrm{L}$ and median insulin level was $66 \mathrm{pmol} / \mathrm{L}$ (IQR: 41-127). 227 Participants with the lowest serum 25(OH)D concentrations were more likely 228 to be older $(P<0.0001)$, had a higher $\mathrm{BMI}(\mathrm{P}=0.002)$, a lower physical activity 229 level $(P=0.006)$, more depressive symptoms $(P=0.009)$ and were more likely 230 to be included in the study during the winter months $(<0.0001)$ (Table I).

232 Vitamin D and cognitive performance

233 Unadjusted models showed that low serum 25(OH)D was associated with a 234 higher probability of a poor performance on all four cognitive domains (Table 235 II). After full adjustment only the association of serum 25(OH)D with attention 236 and working memory remained significant, showing that participants in the 237 upper $25(\mathrm{OH}) \mathrm{D}$ tertile had a $50 \%$ lower probability of being a poor performer. 238 For associations with executive function and episodic memory a non239 significant trend remained. Specifically, for executive function, people in the 240 second and third tertile had a 50\% lower (PR $0.50(95 \% \mathrm{Cl} 0.29-0.86)$ and $24133 \%$ borderline non-significant lower (PR 0.67 (95\% Cl 0.38-1.16)) probability 
of a poor performance. A borderline significant association was observed for

243 episodic memory, PR $0.75(0.55-1.03)$ for the upper serum 25(OH)D tertile.

244 Additional adjustment for depression or creatinine did not alter these results.

246 Vitamin D and glucose homeostasis

247 Tests for non-linearity of the restricted cubic splines showed that the dose-

248 response association of serum $25(\mathrm{OH}) \mathrm{D}$ status with log-transformed plasma

249 glucose and plasma insulin could be considered linear (figures not shown).

250 Subsequently, multiple linear regression analyses showed significant

251 associations for serum 25(OH)D with plasma insulin after adjustment for age 252 and sex, $\beta-0.003(P=0.02)$. However, in the fully adjusted regression 253 analyses this association attenuated and became non-significant, $\beta$ for 254 plasma insulin $-0.001(P=0.31)$.

255

256 Glucose homeostasis and domain-specific cognitive performance

257 In fully adjusted models, only a significant association between plasma 258 glucose and attention and working memory was observed, PR 1.01 (1.00259 1.02) per 0.1 unit increase in plasma glucose, which roughly suggests a $10 \%$ 260 higher probability of being a poor performer with every 1-unit increase in 261 plasma glucose. Plasma glucose and plasma insulin did not significantly 262 associate with any of the other cognitive outcome measures (data not shown). 263 
264 Cognitive performance and the interplay of serum $25(\mathrm{OH}) \mathrm{D}$ and glucose 265 homeostasis

266 The above-mentioned findings imply that there is no mediation effect by 267 glucose homeostasis in the associations between serum 25(OH)D and 268 domain-specific cognitive performance (summarized in Figure I). Exploration 269 of a potential modification effect of plasma glucose and plasma insulin (5) only 270 showed a significant interaction of plasma insulin with serum 25(OH)D for the 271 domain executive function $(\mathrm{P}=0.001)$, indicating a stronger association 272 between serum 25(OH)D with executive function when having high plasma 273 insulin concentrations compared to low plasma insulin concentrations 274 (supplementary Figure II). 


\section{Discussion}

276 In this study, serum 25(OH)D was associated with attention and working 277 memory in community-dwelling older adults $\geq 65$ years. Borderline significant 278 trends for associations of serum 25(OH)D with executive function and 279 episodic memory were observed. There was not convincing evidence for an 280 interplay between serum 25(OH)D and glucose homeostasis in these 281 associations.

282 Already several studies investigated the association between blood 25(OH)D 283 concentrations and global cognitive performance ${ }^{1,13}$, but only some focussed 284 on specific cognitive domains ${ }^{8,9,11,14-18}$. In line with our results on higher 285 serum $25(\mathrm{OH}) \mathrm{D}$ concentrations and better attention and working memory, participants of the NAME study $(n=1069){ }^{14}$ and the ZENITH study $(n=387){ }^{16}$ also performed better on tasks related to working memory with increasing 25(OH)D concentration. In the ISAAC study $(n=159)^{15}$, a trend towards an 289 association between 25(OH)D concentration and the domain working memory was observed. We furthermore observed a trend towards an association 291 between serum 25(OH)D and executive function. Four other studies also 292 provided evidence for a potential role of serum $25(\mathrm{OH}) \mathrm{D}$ in executive function $2938,11,14,17$. Conversely, data of the MrOS $(n=1559){ }^{18}$ and the ISAAC study ${ }^{15}$ did 294 not support an association between serum 25(OH)D and executive function. 295 The association between serum 25(OH)D and episodic memory has also 296 been studied before, but none of these studies observed a trend association 297 as shown in our study 9,14-16,34. McGrath and colleagues showed in the 
NHANES III ( $n=4809)$ that, in contrast to their hypothesis, older adults with 299 higher serum 25(OH)D levels had worse memory and learning scores after 300 adjustment for age, sex, ethnicity and physical activity ${ }^{34}$. We did not observe 301 an association between serum 25(OH)D and information processing speed, 302 which is in line with results of the ZENITH study ${ }^{16}$. In contrast, the European 303 Male Ageing study ${ }^{9}$ and the NAME study ${ }^{14}$ have shown significant 304 associations of serum 25(OH)D with information processing speed tasks. 305 Trials examining the effect of vitamin D on cognitive performance are scarce 306 and most of them were suboptimal, having a small sample size, being 307 relatively short term, or lacking a control group ${ }^{35-38}$.

308 Mechanistic studies suggest a role for vitamin $D$ in the production of 309 neurotrophins and neurotransmitters, inflammation, oxidative stress and 310 excitotoxicity, which may influence neurogenesis, neurotransmission, synaptic 311 plasticity as well as neuronal survival ${ }^{4}$. Based upon previous 312 neuropsychological findings in observational studies, Annweiler and 313 colleagues proposed that low vitamin D levels may be particularly associated 314 with executive dysfunction, and as such with dysfunction of frontal-subcortical 315 neuronal circuits ${ }^{39}$. In our study a significant association was shown between $31625(\mathrm{OH}) \mathrm{D}$ and attention and working memory; trends were observed for 317 executive function and episodic memory. Explanations for these findings may 318 lie in the fact that conceptually, the domains executive function and working 319 memory overlap, as reflected in strong correlations between tasks of working 320 memory and executive function ( $r=0.97)^{40}$, and that executive function and 
321 working memory by themselves may determine episodic memory task 322 performance ${ }^{40}$. Due to this conceptual overlap between the specific brain 323 functions ${ }^{40}$, it is challenging to identify what specific brain regions are affected 324 in case of low 25(OH)D concentrations. A mechanistic explanation for the 325 observed associations and trends in the different cognitive domains may lie in 326 the vascular hypothesis. More specifically, it has been shown that patients 327 with vascular dementia patients often experience deficits in executive 328 functioning and episodic memory ${ }^{41}$. Since we also observed associations or 329 tendencies on these domains - and with that considering the conceptual 330 overlap in the domains executive functioning and attention and working 331 memory - it may be postulated that vascular pathways are involved. However, 332 in order to get more insight in such an underlying mechanism, imaging studies 333 on measures of white matter hyperintensity volume and grade, large vessels 334 infarcts, and small vessel infarcts would be very valuable.

335 To further explore these underlying mechanisms linking vitamin D to cognitive 336 performance, we explored the potential modification and mediation effect of 337 markers related to glucose homeostasis in the association between serum 338 25(OH)D and cognitive performance, showing that plasma glucose or plasma 339 insulin did not mediate the pathway between serum 25(OH)D and cognitive 340 performance. Our analyses did reveal a significant interaction of serum $34125(\mathrm{OH}) \mathrm{D}$ with plasma insulin on the domain executive function. To the best of 342 our knowledge, this is the first study examining the role of glucose 343 homeostasis in this detail. Four other studies adjusted for type 2 diabetes or 
344 surrogate markers of type 2 diabetes in the association between serum $34525(\mathrm{OH}) \mathrm{D}$ and cognitive performance ${ }^{8-11}$; only the NHANES III data suggested 346 that type 2 diabetes may be involved ${ }^{10}$.

347 Our participants were mainly community-dwelling Caucasian men and women 348 with a slightly elevated homocysteine concentration ( $\geq 12 \mu \mathrm{mol} / \mathrm{L})$. Even 349 though a substantial proportion of the Dutch older adults have such an 350 elevated level ${ }^{42}$, our findings may not be generalizable to other populations. 351 Specifically, elevated homocysteine concentrations have been associated with 352 cognitive decline, which may be due to a potentially toxic effect of 353 homocysteine on neurons and vascular endothelial cells ${ }^{43,44}$. Hence, 354 cognitive problems may be somewhat more likely to be present in the B355 PROOF population as compared to the general population. Another limitation 356 of this study is the cross-sectional design. We observed that $25(\mathrm{OH}) \mathrm{D}$ 357 concentrations were higher in persons with a better attention and working 358 memory. Consequently, we suggest that the lower 25(OH)D concentrations 359 may result in a poorer attention and working memory. However, it is also 360 plausible that participants with a poor attention and working memory were less 361 likely to go outside and that the low 25(OH)D concentrations are the result of 362 the poor cognitive performance observed. Another limitation is the fact that 363 participants were allowed to consume a restricted breakfast. Therefore, the 364 plasma glucose and plasma insulin concentrations measured cannot be 365 considered fasted. Consequently, associations in this study with plasma 366 glucose and insulin as the outcome may have been biased towards the null. 
Associations with plasma glucose and plasma insulin as the exposure may be underestimated. Strengths of this study are the extensive cognitive test battery used, its large sample size, the possibility to adjust for a large number of potential confounders, and the fact that we had the possibility to further explore the potential role of glucose homeostasis in the association between serum 25(OH)D and cognitive performance.

In all, we conclude that this study points towards a link between serum 25(OH)D and cognitive performance, specifically attention and working memory. Notwithstanding some significant findings, this study did not provide convincing evidence for an interplay between serum 25(OH)D and glucose homeostasis in association with cognitive performance. The fact that we mainly observed non-significant trends for the associations between serum 25(OH)D and cognitive performance may be because our participants were relatively young and healthy to show a clear clinical manifestation of cognitive problems, which is also suggested by the high MMSE score of this population. It may for instance be that the brains of our participants did already function less efficiently, but that this less efficient functioning was compensated for via the activation of alternative brain networks ${ }^{45}$, and therefore difficult to detect with the paper-pencil tests that were used in this study. In future studies it might therefore be interesting to further explore this potential 'compensatory' mechanism by including brain activity measurements, for instance by using near-infrared spectroscopy (NIRS), functional Magnetic Resonance Imaging (fMRI), or electroencephalorgraphy (EEG). 
391 Acknowledgements / conflict of interest

392 The authors gratefully thank all study participants, and all dedicated co-workers who 393 helped to succeed this trial, especially Mrs. M. Hillen-Tijdink, Mrs. A. Nicolaas394 Merkus, Mrs. N. Pliester, Ms. S. Oliai Araghi, MSc., and Mrs. S. Smits, R.N. They 395 also thank Prof. Dr. H.A.P. Pols for obtaining funding. This study was part of the B396 PROOF Study (B-vitamins for the PRevention of OsteOPorotic Fractures). B-PROOF 397 is supported and funded by The Netherlands Organization for Health Research and 398 Development (ZonMw, Grant 6130.0031), the Hague; unrestricted grant from NZO 399 (Dutch Dairy Association), Zoetermeer; MCO Health, Almere; NCHA (Netherlands 400 Consortium Healthy Ageing) Leiden/ Rotterdam; Ministry of Economic Affairs, 401 Agriculture and Innovation (project KB-15-004-003), the Hague; Wageningen 402 University, Wageningen; VU University Medical Center, Amsterdam; Nutricia 403 Research Foundation; the Graduate School VLAG. 
1. Balion C, Griffith LE, Strifler L, et al. Vitamin D, cognition, and dementia: A

2. Annweiler C, Beauchet O. Vitamin D-mentia: randomized clinical trials should be the next step. Neuroepidemiology. 2011;37(3-4):249-258.

3. Eyles DW, Burne TH, McGrath JJ. Vitamin D, effects on brain development, adult brain function and the links between low levels of vitamin $\mathrm{D}$ and neuropsychiatric disease. Front Neuroendocrinol. Jul 112012.

4. McCann JC, Ames BN. Is there convincing biological or behavioral evidence linking vitamin D deficiency to brain dysfunction? FASEB J. Apr 2008;22(4):982-1001.

5. Brouwer-Brolsma EM, de Groot LC. Vitamin D and cognition in older adults: an update of recent findings. Current opinion in clinical nutrition and metabolic care. Jan 2015;18(1):11-16.

6. Pittas AG, Lau J, Hu FB, Dawson-Hughes B. The role of vitamin D and calcium in type 2 diabetes. A systematic review and meta-analysis. The Journal of clinical endocrinology and metabolism. Jun 2007;92(6):2017-2029.

7. Biessels GJ, Staekenborg S, Brunner E, Brayne C, Scheltens P. Risk of dementia in diabetes mellitus: a systematic review. Lancet Neurol. Jan 2006;5(1):64-74.

8. Brouwer-Brolsma EM, van de Rest O, Tieland M, et al. Serum 25hydroxyvitamin $\mathrm{D}$ is associated with cognitive executive function in dutch prefrail and frail elderly: a cross-sectional study exploring the associations of 25-hydroxyvitamin D with glucose metabolism, cognitive performance and depression. Journal of the American Medical Directors Association. Nov 2013;14(11):852 e859-817.

9. Lee DM, Tajar A, Ulubaev A, et al. Association between 25-hydroxyvitamin D levels and cognitive performance in middle-aged and older European men. $J$ Neurol Neurosurg Psychiatry. Jul 2009;80(7):722-729.

10. Llewellyn DJ, Lang IA, Langa KM, Melzer D. Vitamin D and cognitive impairment in the elderly U.S. population. J Gerontol A Biol Sci Med Sci. Jan 2010;66(1):59-65.

11. Llewellyn DJ, Lang IA, Langa KM, et al. Vitamin D and risk of cognitive decline in elderly persons. Arch Intern Med. Jul 12 2010;170(13):1135-1141.

12. Brouwer-Brolsma EM, Schuurman T, de Groot LC, et al. No role for vitamin $\mathrm{D}$ or a moderate fat diet in aging induced cognitive decline and emotional reactivity in C57BL/6 mice. Behavioural brain research. Jul 1 2014;267:133143.

13. Brouwer-Brolsma EM, Feskens EJ, Steegenga WT, de Groot LC. Associations of 25-hydroxyvitamin D with fasting glucose, fasting insulin, dementia and depression in European elderly: the SENECA study. Eur J Nutr. Jun 232012.

14. Buell JS, Scott TM, Dawson-Hughes B, et al. Vitamin D is associated with cognitive function in elders receiving home health services. J Gerontol A Biol Sci Med Sci. Aug 2009;64(8):888-895. 
15. Peterson A, Mattek N, Clemons A, et al. Serum vitamin D concentrations are associated with falling and cognitive function in older adults. $J$ Nutr Health Aging. Oct 2012;16(10):898-901.

16. Seamans KM, Hill TR, Scully L, et al. Vitamin D status and measures of cognitive function in healthy older European adults. European journal of clinical nutrition. Oct 2010;64(10):1172-1178.

17. Slinin Y, Paudel M, Taylor BC, et al. Association between serum 25(OH) vitamin $\mathrm{D}$ and the risk of cognitive decline in older women. $J$ Gerontol A Biol Sci Med Sci. Oct 2012;67(10):1092-1098.

18. Slinin Y, Paudel ML, Taylor BC, et al. 25-Hydroxyvitamin D levels and cognitive performance and decline in elderly men. Neurology. Jan 5 2010;74(1):33-41.

19. van Wijngaarden JP, Dhonukshe-Rutten RA, van Schoor NM, et al. Rationale and design of the B-PROOF study, a randomized controlled trial on the effect of supplemental intake of vitamin B12 and folic acid on fracture incidence. BMC geriatrics. 2011;11:80.

20. Folstein MFF, S.E.; McHugh, P.R. "Mini-mental state". A practical method for grading the cognitive state of patients for the clinician. Journal of Psychiatric Research. 1975;12(3):189-198.

21. Brand N, Jolles J. Learning and retrieval rate of words presented auditorily and visually. J Gen Psychol. Apr 1985;112(2):201-210.

22. Wechsler D. Manual for the Adult Intelligence Scale-Revised. New York: Psychological Corporation; 1981.

23. Reitan RM. Validity of the trail-making test as an indicator of organic brain damage. Perceptual and Motor Skills. 1958;8:271-276.

24. Stroop J. Studies of interference in serial verbal reactions. Journal of Experimental Psychology. 1935;18:643-662.

25. Smith A. Symbol Digits Modalities Test. Los Angeles1982.

26. Lezak MD. Neurospychological assessment. New York: Oxford University Press; 2004.

27. Ganguli M, Belle S, Ratcliff G, et al. Sensitivity and specificity for dementia of population-based criteria for cognitive impairment: the MoVIES project. Journal of gerontology. Jul 1993;48(4):M152-161.

28. Heijboer AC, Blankenstein MA, Kema IP, Buijs MM. Accuracy of 6 routine 25-hydroxyvitamin D assays: influence of vitamin D binding protein concentration. Clin Chem. Mar;58(3):543-548.

29. Stel VS, Smit JH, Pluijm SM, Visser M, Deeg DJ, Lips P. Comparison of the LASA Physical Activity Questionnaire with a 7-day diary and pedometer. Journal of clinical epidemiology. Mar 2004;57(3):252-258.

30. Garretsen H. Probleemdrinken, Prevalentiebepaling, Beinvloedende Factoren en Preventiemogelijkheden, Theoretische Overwegingen en Onderzoek in Rotterdam. Lisse, The Netherlands: Swets \& Zeitlinger; 2003.

31. Almeida OP, Almeida SA. Short versions of the geriatric depression scale: a study of their validity for the diagnosis of a major depressive episode according to ICD-10 and DSM-IV. International journal of geriatric psychiatry. Oct 1999;14(10):858-865. 
32. Barros AJ, Hirakata VN. Alternatives for logistic regression in cross-sectional studies: an empirical comparison of models that directly estimate the prevalence ratio. BMC medical research methodology. Oct 20 2003;3:21.

33. Ross AC, Taylor, C.L., Yaktine, A.L., Del Valle, H.B., editors. . Dietary Reference Intakes for Calcium and Vitamin D. 2011.

34. McGrath J, Scragg R, Chant D, Eyles D, Burne T, Obradovic D. No association between serum 25-hydroxyvitamin D3 level and performance on psychometric tests in NHANES III. Neuroepidemiology. 2007;29(1-2):49-54.

35. Annweiler C, Fantino B, Gautier J, Beaudenon M, Thiery S, Beauchet O. Cognitive effects of vitamin D supplementation in older outpatients visiting a memory clinic: a pre-post study. J Am Geriatr Soc. Apr 2012;60(4):793-795.

36. Annweiler C, Herrmann FR, Fantino B, Brugg B, Beauchet O. Effectiveness of the combination of memantine plus vitamin $D$ on cognition in patients with Alzheimer disease: a pre-post pilot study. Cogn Behav Neurol. Sep 2012;25(3):121-127.

37. Corless D, Dawson E, Fraser F, et al. Do vitamin D supplements improve the physical capabilities of elderly hospital patients? Age and ageing. Mar 1985;14(2):76-84.

38. Stein MS, Scherer SC, Ladd KS, Harrison LC. A randomized controlled trial of high-dose vitamin D2 followed by intranasal insulin in Alzheimer's disease. Journal of Alzheimer's disease : JAD. 2011;26(3):477-484.

39. Annweiler C, Montero-Odasso M, Muir SW, Beauchet O. Vitamin D and Brain Imaging in the Elderly: Should we Expect Some Lesions Specifically Related to Hypovitaminosis D? Open Neuroimag J. 2012;6:16-18.

40. McCabe DP, Roediger HL, McDaniel MA, Balota DA, Hambrick DZ. The Relationship Between Working Memory Capacity and Executive Functioning: Evidence for a Common Executive Attention Construct. Neuropsychology. Mar 2010;24(2):222-243.

41. van der Flier W. Vascular dementia Neuroimaging in Dementia. BerlinHeidelberg: Springer-Verlag; 2011:171-172.

42. de Bree A, van der Put NM, Mennen LI, et al. Prevalences of hyperhomocysteinemia, unfavorable cholesterol profile and hypertension in European populations. European journal of clinical nutrition. Apr 2005;59(4):480-488.

43. Smith AD. The worldwide challenge of the dementias: a role for B vitamins and homocysteine? Food and nutrition bulletin. Jun 2008;29(2 Suppl):S143172.

44. Ford AH, Almeida OP. Effect of homocysteine lowering treatment on cognitive function: a systematic review and meta-analysis of randomized controlled trials. Journal of Alzheimer's disease : JAD. 2012;29(1):133-149.

45. Tucker AM, Stern Y. Cognitive reserve in aging. Current Alzheimer research. Jun 2011;8(4):354-360.

46. American Diabetes A. Diagnosis and classification of diabetes mellitus. Diabetes care. Jan 2013;36 Suppl 1:S67-74. 
539

540

541

542
47. Farmacotherapeutisch Kompas. 2015;

https://http://www.farmacotherapeutischkompas.nl/voorna/i/inl

referentiewaarden klinische chemie.asp. Accessed 7-2-2015, 2015. 
Table I. Population characteristics, overall and by tertile of serum 25(OH)D.

\begin{tabular}{|c|c|c|c|c|c|c|}
\hline & $\begin{array}{c}\text { Total } \\
\text { population }\end{array}$ & $\begin{array}{c}\text { Cognition } \\
\text { subsample }\end{array}$ & $\begin{array}{r}\mathrm{Cc} \\
\text { by ter }\end{array}$ & $\begin{array}{l}\text { hition subsamp } \\
\text { e of serum } 25 \text { ( }\end{array}$ & H)D & P-value \\
\hline & & & $\begin{array}{c}\mathrm{T} 1 \\
<47 \mathrm{nmol} / \mathrm{L}\end{array}$ & $\begin{array}{c}\mathrm{T} 2 \\
47-70 \mathrm{nmol} / \mathrm{L}\end{array}$ & $\begin{array}{c}\mathrm{T} 3 \\
>70 \mathrm{nmol} / \mathrm{L}\end{array}$ & \\
\hline $\mathrm{N}$ & 2857 & 846 & 280 & 286 & 280 & \\
\hline $\begin{array}{l}\text { 25(OH)D } \\
(\mathrm{nmol} / \mathrm{L})^{*}\end{array}$ & $56 \pm 25$ & $60 \pm 26$ & $33 \pm 10$ & $59 \pm 7$ & $89 \pm 17$ & $<0.0001$ \\
\hline Sex, men (\%) & $1459(50)$ & 495 (59) & $149(53)$ & $174(61)$ & $172(61)$ & 0.09 \\
\hline Age, years & $74.1 \pm 6.5$ & $72.5 \pm 5.7$ & $74.1 \pm 6.6$ & $72.1 \pm 5.2$ & $71.4 \pm 4.7$ & $<0.0001$ \\
\hline $\begin{array}{l}\text { Body Mass Index, } \\
\mathrm{kg} / \mathrm{m}^{2}\end{array}$ & $27.1 \pm 4.0$ & $27.2 \pm 3.9$ & $27.5 \pm 4.4$ & $27.6 \pm 3.8$ & $26.5 \pm 3.3$ & 0.002 \\
\hline $\begin{array}{l}\text { Glucose } \\
(\mathrm{mmol} / \mathrm{L})^{\star \star}\end{array}$ & - & $5.8 \pm 1.4$ & $5.7 \pm 1.3$ & $5.9 \pm 1.5$ & $5.8 \pm 1.6$ & 0.50 \\
\hline Insulin (pmol/L) ${ }^{\star \star \star}$ & - & $66(41-127)$ & 71 (44-133) & $68(44-136)$ & $61(38-105)$ & 0.23 \\
\hline $\begin{array}{l}\text { Creatinine } \\
(\mu \mathrm{mol} / \mathrm{L})\end{array}$ & $83.9 \pm 18.2$ & $84.6 \pm 18.2$ & $81.4 \pm 17.9$ & $85.3 \pm 18.2$ & $87.0 \pm 18.1$ & 0.001 \\
\hline $\begin{array}{l}\text { Smoking, n (\%) } \\
\text { Non } \\
\text { Current } \\
\text { Former }\end{array}$ & $\begin{array}{c}989(34) \\
281(10) \\
1649(56)\end{array}$ & $\begin{array}{c}261(31) \\
86(10) \\
499(59)\end{array}$ & $\begin{array}{c}80(29) \\
34(12) \\
166(59)\end{array}$ & $\begin{array}{c}89(31) \\
29(10) \\
168(59)\end{array}$ & $\begin{array}{c}92(33) \\
23(8) \\
165(59)\end{array}$ & 0.56 \\
\hline $\begin{array}{l}\text { Physical activity } \\
\text { (kcal/day) }\end{array}$ & $\begin{array}{c}650 \\
(343-826) \\
\end{array}$ & $\begin{array}{c}573 \\
(344-859) \\
\end{array}$ & $\begin{array}{c}496 \\
(289-785) \\
\end{array}$ & $\begin{array}{c}581 \\
(382-874) \\
\end{array}$ & $\begin{array}{c}625 \\
(386-894) \\
\end{array}$ & 0.006 \\
\hline $\begin{array}{l}\text { Physical } \\
\text { performance } \\
\text { score }(0-12)\end{array}$ & $8.1 \pm 3.2$ & $8.6 \pm 2.8$ & $7.7 \pm 3.0$ & $8.9 \pm 2.6$ & $9.3 \pm 2.4$ & $<0.0001$ \\
\hline $\begin{array}{l}\text { \# falls (12 months } \\
\text { prior to baseline) } \\
0 \\
1 \\
2\end{array}$ & $\begin{array}{l}1498(68) \\
458(21) \\
258(12) \\
\end{array}$ & $\begin{array}{l}363(67) \\
117(21) \\
66(23) \\
\end{array}$ & $\begin{array}{l}123(64) \\
46(24) \\
22(12) \\
\end{array}$ & $\begin{array}{l}132(69) \\
37(19) \\
23(12) \\
\end{array}$ & $\begin{array}{l}108(66) \\
34(21) \\
21(13) \\
\end{array}$ & 0.83 \\
\hline $\begin{array}{l}\text { Education, n (\%) } \\
\text { Primary } \\
\text { Secondary } \\
\text { Higher }\end{array}$ & $\begin{array}{l}1547(53) \\
615(21) \\
757(26) \\
\end{array}$ & $\begin{array}{l}362(43) \\
187(22) \\
297(35) \\
\end{array}$ & $\begin{array}{l}122(44) \\
63(23) \\
95(34) \\
\end{array}$ & $\begin{array}{l}127(44) \\
65(23) \\
94(33) \\
\end{array}$ & $\begin{array}{c}113(40) \\
59(21) \\
108(39) \\
\end{array}$ & 0.68 \\
\hline $\begin{array}{l}\text { Alcohol intake, } \mathrm{n} \\
(\%) \\
\text { Light } \\
\text { Moderate } \\
\text { Excessive }\end{array}$ & $\begin{array}{c}1966(67) \\
839(29) \\
112(4) \\
\end{array}$ & $\begin{array}{c}546(65) \\
271(32) \\
29(3) \\
\end{array}$ & $\begin{array}{c}201(72) \\
68(24) \\
11(4) \\
\end{array}$ & $\begin{array}{c}171(60) \\
105(37) \\
10(3) \\
\end{array}$ & $\begin{array}{c}174(62) \\
98(35) \\
8(3) \\
\end{array}$ & 0.02 \\
\hline $\begin{array}{l}\text { MMSE } \\
\text { (range 0-30) }\end{array}$ & $29(28-30)$ & $29(28-30)$ & $29(27-30)$ & $29(28-30)$ & $29(28-30)$ & 0.16 \\
\hline $\begin{array}{l}\text { GDS-15 } \\
\text { (range 0-15) }\end{array}$ & $1.0(0-2.0)$ & $1.0(0-2.0)$ & $1.0(0-2.0)$ & $1.0(0-2.0)$ & $0(0-2.0)$ & 0.009 \\
\hline $\begin{array}{l}\text { Cardiac disease, } \\
\mathrm{n}(\%)\end{array}$ & $557(25)$ & $136(25)$ & $57(30)$ & $44(23)$ & 35 (22) & 0.15 \\
\hline TIA/stroke, n (\%) & $193(9)$ & $40(7)$ & $19(10)$ & $12(6)$ & $9(6)$ & 0.20 \\
\hline $\begin{array}{l}\text { Kidney disease, } \mathrm{n} \\
(\%)\end{array}$ & $57(3)$ & $13(2)$ & $4(2)$ & $5(3)$ & $4(2)$ & 0.95 \\
\hline $\begin{array}{l}\text { Hypertension, } n \\
(\%)\end{array}$ & 863 (39) & $219(41)$ & $73(38)$ & $80(42)$ & $66(41)$ & 0.73 \\
\hline Blood sampling & $1531(52)$ & $552(65)$ & $145(52)$ & $191(67)$ & $216(77)$ & $<0.0001$ \\
\hline
\end{tabular}


from June -

November.

\begin{tabular}{|l|l|l|l|}
\hline & & & \\
\hline
\end{tabular}

544 MMSE=Mini-Mental State Examination. GDS-15 = Geriatric Depression Scale-15. T=Tertile.

545 Values are presented as mean $\pm S D$, or median (IQR). P-value refers to differences between 546 tertiles. Missings ( $n$ ) for the cognition subsample: BMI (1), glucose (11), insulin (10), 547 creatinine (2), physical activity (2), physical performance score (1), fall frequency 12 months 548 prior to baseline (300), MMSE (14), GDS-15 (7), cardiac disease (304), TIA/stroke $(n=305)$, 549 kidney disease $(n=305)$, hypertension $(n=306)$. ${ }^{*}$ Currently the Institute of Medicine considers 550 a $25(\mathrm{OH}) \mathrm{D}$ concentration $<50 \mathrm{nmol} / \mathrm{L}$ as being insufficient ${ }^{33}$. ${ }^{* *}$ For blood glucose the 551 American Diabetic Association considers a fasting plasma concentration between 5.6 and 6.9 $\mathrm{mmol} / \mathrm{L}$ indicative of an impaired glucose metabolism (pre-diabetes), a concentration $\geq 7.0$

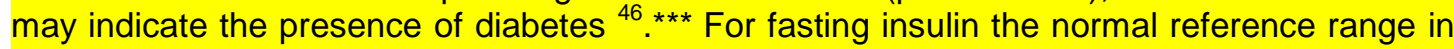
the Netherlands is considered to be $<118 \mathrm{pmol} / \mathrm{L}$ for normal weight persons and $<180 \mathrm{pmol} / \mathrm{L}$ for obsess persons ${ }^{47}$. 
Table II. Associations of serum 25(OH)D with domain-specific cognitive performance. Shown by Prevalence Ratios (PRs) with 95\% Confidence Interval (Cl) by tertile of serum 559 25(OH)D.

\begin{tabular}{|c|c|c|c|c|}
\hline & \multicolumn{4}{|c|}{ Prevalence Ratio's by tertile of serum 25(OH)D (nmol/L) } \\
\hline $\begin{array}{l}\text { WUR } \\
\text { (total population) }\end{array}$ & $\begin{array}{c}\text { T1: } 4-47 \\
(4-42)\end{array}$ & $\begin{array}{c}\text { T2: } 47-70 \\
(42-65)\end{array}$ & $\begin{array}{c}\text { T3: } 70-194 \\
(65-194)\end{array}$ & $\mathrm{P}$ for trend \\
\hline AWM, n (cases)* & $263(38)$ & $262(27)$ & $262(18)$ & \\
\hline Crude model & 1.0 & $0.71(0.45-1.13)$ & $0.48(0.28-0.81)$ & 0.005 \\
\hline Model 1 & 1.0 & $0.71(0.45-1.15)$ & $0.48(0.28-0.84)$ & 0.008 \\
\hline Model 2 & 1.0 & $0.72(0.45-1.15)$ & $0.50(0.29-0.84)$ & 0.008 \\
\hline $\mathrm{EF}, \mathrm{n}$ (cases)* & $254(40)$ & $260(17)$ & $262(19)$ & \\
\hline Crude model & 1.0 & $0.41(0.24-0.71)$ & $0.46(0.27-0.77)$ & 0.004 \\
\hline Model 1 & 1.0 & $0.49(0.28-0.85)$ & $0.56(0.33-0.98)$ & 0.04 \\
\hline Model 2 & 1.0 & $0.50(0.29-0.86)$ & $0.67(0.38-1.16)$ & 0.13 \\
\hline IPS, n (cases)* & $260(32)$ & $267(29)$ & $270(19)$ & \\
\hline Crude model & 1.0 & $0.88(0.55-1.42)$ & $0.57(0.33-0.98)$ & 0.04 \\
\hline Model 1 & 1.0 & $1.38(0.86-2.20)$ & $0.97(0.57-1.66)$ & 0.95 \\
\hline Model 2 & 1.0 & $1.47(0.93-2.33)$ & $1.03(0.60-1.78)$ & 0.86 \\
\hline EM, n (cases)* & $896(108)$ & $918(96)$ & $908(70)$ & \\
\hline Crude model & 1.0 & $0.87(0.67-1.12)$ & $0.64(0.48-0.85)$ & 0.002 \\
\hline Model 1 & 1.0 & $1.02(0.79-1.32)$ & $0.77(0.58-1.03)$ & 0.07 \\
\hline Model 2 & 1.0 & 0.99 (0.76-1.29) & $0.75(0.55-1.03)$ & 0.07 \\
\hline
\end{tabular}

*Participants were characterized as poor cognitive performers when cognitive test scores fell below the 10th percentile. Model 1 is adjusted for age and sex. Model 2 is adjusted for age, sex, BMI, education, alcohol consumption, smoking, physical activity, season of blood sampling and centre. None of the PRs substantially changed after additional adjustment for depression, plasma glucose or plasma insulin. $\mathrm{AWM}=$ Attention and Working Memory. EF= Executive Function. IPS = Information Processing Speed. EM = Episodic Memory. $\mathrm{PR}=$ Prevalence Ratio's. WUR: subpopulation measured at Wageningen University. 
570 Figure I. Overview of the associations studied. The associations are

571 displayed per cognitive domain, where Figure 1A shows the associations for

572 'attention and working memory', 1B for the domain 'executive functioning', 1C 573 for the domain 'information processing speed', and 1D for the domain 574 'episodic memory'. Per subfigure, associations are shown for (1) serum $57525(\mathrm{OH}) \mathrm{D}$ with the particular cognitive domains, (2) serum 25(OH)D with 576 glucose homeostasis, (3) glucose homeostasis and the particular cognitive 577 domains, (4) serum 25(OH)D and the particular cognitive domains that were 578 adjusted for either plasma glucose or plasma insulin, and (5) association of 579 serum $25(\mathrm{OH}) \mathrm{D}$ and the particular cognitive domains, explored for potential 580 modification by plasma glucose and plasma insulin. 
(1) Yes

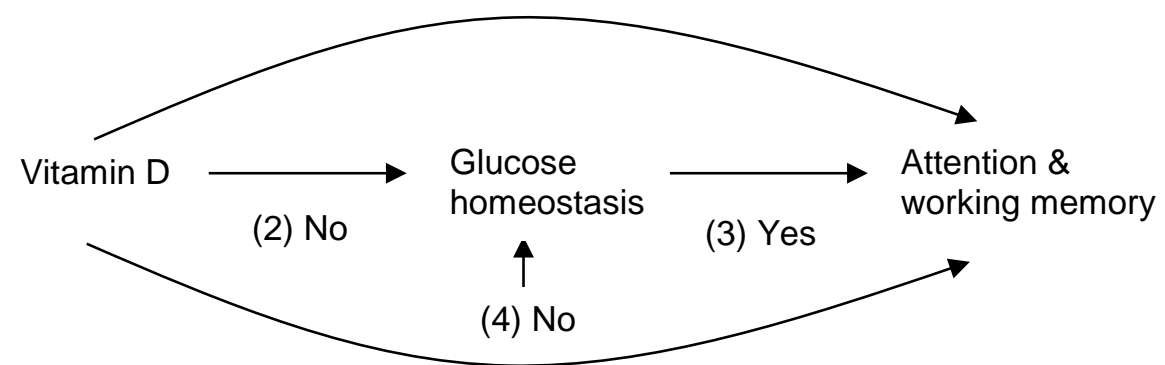

(5) Vitamin $D^{*}$ Glucose: No, but trend Vitamin D*Insulin: No

B

(1) No, but trend

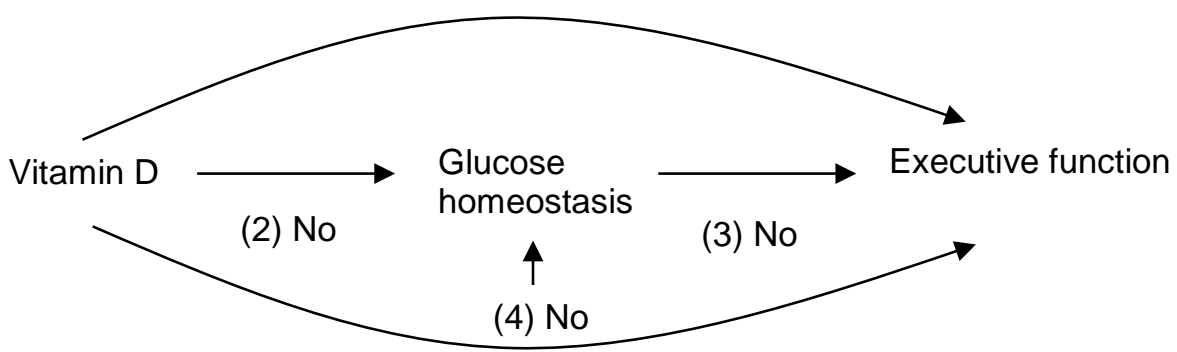

(5) Vitamin $D^{*}$ Glucose: No, but trend Vitamin $D^{*}$ Insulin: Yes

C

(1) No

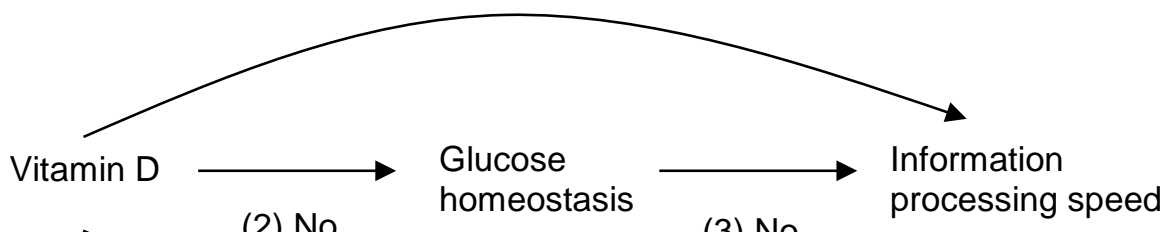

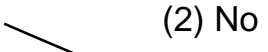

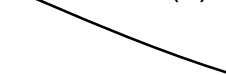

$\uparrow$

(4) No

(5) Vitamin $D^{*}$ Glucose: No

Vitamin $D^{*}$ Insulin: No

D

(1) No, but trend

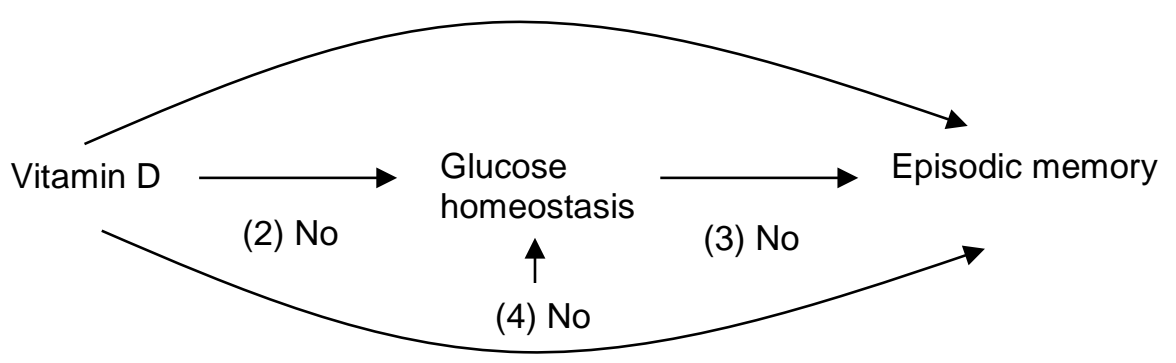

(5) Vitamin $D^{*}$ Glucose: No Vitamin $D^{*}$ Insulin: No 


\section{Acknowledgements}

The authors gratefully thank all study participants, and all dedicated co-workers who helped to succeed this trial, especially Mrs. M. Hillen-Tijdink, Mrs. A. Nicolaas-Merkus, Mrs. N. Pliester, Ms. S. Oliai Araghi, MSc., and Mrs. S. Smits, R.N. They also thank Prof. Dr. H.A.P. Pols for obtaining funding. 
Supplementary Figure I. Flow diagram describing the data used for the statistical analyses.

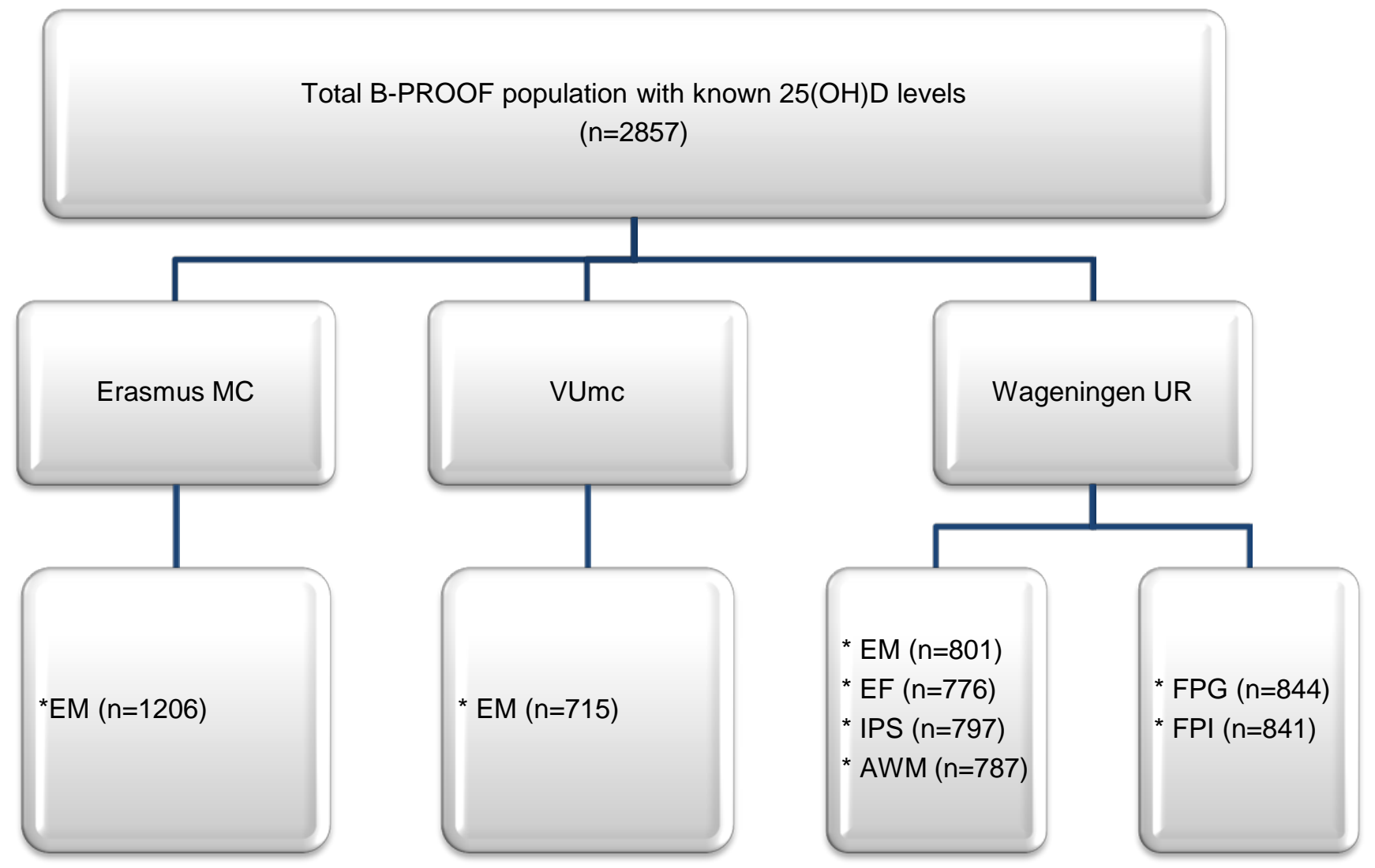

EM=Episodic Memory. EF=Executive Function. IPS= Information Processing Speed. AWM=Attention and Working Memory. FPG=Fasting Plasma

Glucose. FPI=Fasting Plasma Insulin. 
Supplementary Figure II. Associations of serum 25(OH)D with the domain executive function, stratified for (A) plasma glucose and (B) plasma insulin. Associations are shown by Prevalence Ratio's ( $y$-axis). Participants were characterized as poor cognitive performers when cognitive test scores fell below the 10th percentile. Absolute numbers for 25(OH)D*glucose are: $1.14(0.59-2.20), 0.48(0.21-1.12), 0.61(0.22-1.71), 0.58(0.17-2.01), 0.83(0.24-2.88)$; absolute numbers for 25(OH)D*insulin are: 0.71 (0.39-1.30), 0.60 (0.29-1.06), 0.44 (0.18-1.08), 0.65 (0.25-1.68), 0.86 (0.41-1.82).

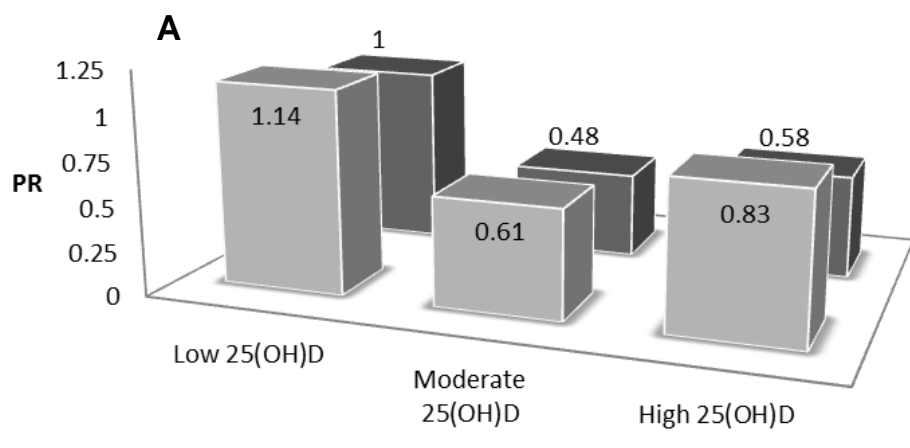

= Glucose $<5.5 \mathrm{mmol} / \mathrm{L}$

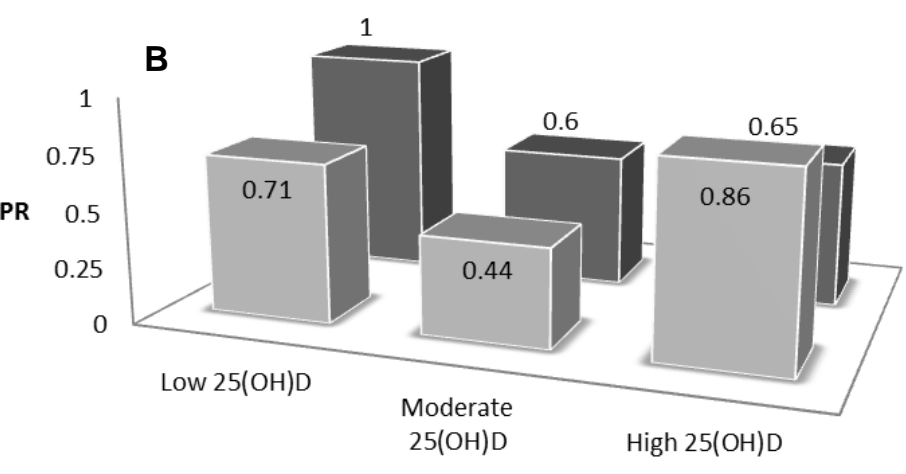

= Insulin $<66 \mathrm{pmol} / \mathrm{L} \quad$ = Insulin $\geq 66 \mathrm{pmol} / \mathrm{L}$ 
Title:

Individual competencies for managers engaged in corporate sustainable management practices
Authors:
Dr. R. Wesselink, Education and Competence Studies, Wageningen University
Dr. V. Blok, Management Studies, Wageningen University
S. van Leur, Student Management Studies, Wageningen University
Dr. T. Lans, Education and Competence Studies, Wageningen University
Dr. D. Dentoni, Management Studies, Wageningen University

Renate Wesselink (Corresponding Author)

Wageningen University, Education and Competence Studies, P.O. Box, 8130, 6700 EW, Wageningen. The Netherlands. Renate.Wesselink@wur.nl, +31 (0) 317484833.

\section{Vincent Blok}

Wageningen University, Management Studies, Social Sciences Group, P.O. Box, 8130, 6700 EW, Wageningen. The Netherlands. Vincent.Blok@wur.nl, +31 (0) 317483623.

\section{Sebastiaan van Leur}

Wageningen University, Management Studies, Social Sciences Group, P.O. Box, 8130, 6700 EW, Wageningen. The Netherlands. Sebastiaan.vanLeur@wur.nl, +31 (0) 317484833.

\section{Thomas Lans}

Wageningen University, Education and Competence Studies, P.O. Box, 8130, 6700 EW, Wageningen. The Netherlands. Thomas.Lans@wur.nl, +31 (0) 317488639.

\section{Domenico Dentoni}

Wageningen University, Management Studies, Social Sciences Group, P.O. Box, 8130, 6700 EW, Wageningen. The Netherlands. Domenico.Dentoni@wur.nl, +31 (0) 317483623.

Word count: 9689 


\begin{abstract}
Corporations increasingly acknowledge the importance of corporate sustainable practices. Corporate social responsibility is therefore gaining significance in the business world. Since solving corporate social responsibility issues is not a routine job, every challenge in corporate social responsibility requires its own approach; and management competencies are crucial for designing appropriate approaches towards the realization of sustainable solutions. On the basis of seven corporate social responsibility competencies synthesized from the extant literature, this research provides an empirical analysis of which of these competencies managers need in order to achieve corporate social responsibility goals within their specific context; and at which specific stage of the implementation process. The data sources are interviews with corporate social responsibility managers - whose positions and circumstances share many similarities - at four large multinational enterprises. The empirical analysis reveals that managers undertake four corporate social responsibility core tasks: I) orientation, II) reaching common ground, III) performing pilot projects, and IV) embedding results. Within the context of the analysis, the competencies: Systems Thinking, Embracing Diversity and Interdisciplinarity, Interpersonal Competence, Action Competence, and Strategic Management were found to be necessary. The Embracing Diversity and Interdisciplinarity competence was identified as the most relevant. This study contributes to the corporate social responsibility (education) literature by introducing an empirical test of which competencies are considered necessary for managers in various stages of corporate social responsibility implementation. Linking these competencies to core tasks makes them more concrete and increases the chances of interpreting them unambiguously, which in turn can aid learning trajectories in both business and education.
\end{abstract}

Keywords: CSR competencies, CSR managers, CSR practices, Sustainability competencies. 


\section{Introduction}

Corporate Social Responsibility (CSR) is gaining significance in the business world, as corporations increasingly recognise the importance of ethical and responsible business practices to their survival and legitimacy (Dunphy et al., 2003). CSR is a business approach to sustainable development wherein companies voluntarily integrate environmental, social, and economic concerns with their business strategies - and into their interactions with stakeholders - in a quest to contribute to society in a sustainable way (Dahlsrud, 2008). This definition emphasises the voluntary nature of CSR, in that businesses engage in CSR-related activities that go beyond compliance to laws and regulations; such voluntary activities have the potential to increase the competitiveness of companies. However, since these activities can be abandoned at any time (Lozano, 2012), it is critical that they be embedded in organisations. In order to distinguish CSR from sustainability in this article, sustainability is defined as the ultimate goal of society at large (Marrewijk and Werre, 2003), whereas CSR concentrates on the contribution of companies to achieve said sustainability goal, for instance by balancing people, planet, and profit in their business practices (Wempe and Kaptein, 2002).

However, the problem is that issues like global warming, poverty, hunger and biodiversity decline cannot be solved in an easy and unilateral way. De Colle and Henriques (2013) underline this with their statement that: "despite being well-intended, CSR standards can favour the emergence of a thoughtless, blind and blinkered mindset which is counterproductive of their aim of enhancing the social responsibility of the organisation" (p. 1). Schwartz and Tilling (2009) paint a more nuanced picture. Although they acknowledge the necessity of standards (e.g. ISO 26000), they argue that CSR standards may lead to the isolation (or decontextualisation) of complex and contested social issues, while favouring their social legitimacy. Sustainability can be enhanced by (international) standards like ISO, but sustainability challenges beyond these standards have to be approached in an interdisciplinary way (e.g., people, planet and profit); by means of collaborations between different stakeholders, in which the time dimension and the context are taken into account as well (cf. Lozano, 2008). This means that sustainability remains a challenge, where every problem or challenge should be studied in its own particular context and time frame. This complexity grows even more because multiple stakeholders like businesses, governments and non-governmental organisations (NGOs) interact in sustainability issues with often conflicting value frames and ideologies (Peterson, 2009); this explains the complexity of many CSR practices as well. This complexity is also partly recognisable in other management areas like quality management or change management, but competing interests and value frames of stakeholders are particularly at stake where it comes to CSR practices.

Dealing with CSR challenges is complex, and strategic and operational decisions have to be taken at the individual level or at the level of an internal (e.g. management team, board of directors) and/or external (e.g. multiple stakeholders) team of individuals with different backgrounds, interests and value frames. Furthermore, because of the complexity of CSR challenges, standard responses will not suffice; what worked in the past does not necessarily work for the future. This explains the importance of the individual level or, as it is framed by Hesselbarth and Schaltegger (2014), the level of "the change agent". Change agents are crucial for the development of the necessary flexibility and adaptability of businesses in dealing with new and changing sustainability challenges, it is assumed that the flexibility and adaptability of change agents lie embedded in individual competencies (Rothaermel and Hess, 2007; Wals, 2010). Although it is clear that the individual level is crucial to the achievement of sustainability goals, current research in business and management literature mainly concentrates on factors affecting or enhancing sustainability performance emanating from the institutional and organisational level (see Aguinis and Glavas, 2012 for a review; Veldhuizen et al., 2013). There is a call for studies on the 
contribution of individuals that may affect organisational CSR-performance (Aguinis and Glavas, 2012). In educational literature (i.e. education for sustainable development), the importance of the individual level is already recognized and better researched.

In Dentoni et al. (2012), CSR competencies in the business context are summarised by making use of existing sets of CSR and sustainable development (SD) competencies provided, for instance, by De Haan (2010) and Wiek et al. (2011). In general, these sets of competencies find their origins in educational literature and are based on literature reviews; without hardly any verification whether or how these competencies are connected with managerial CSR tasks. The goal of this paper is to empirically explore the competencies identified in the extant literature as to which of them enable managers to fulfil core tasks of CSR implementation in a specific business context. Relative to the existing literature then, this research introduces and applies a method for empirically assessing CSR competencies in cases where CSR practices are implemented in other settings. To the best of the authors' knowledge, this is the first study analysing the links between CSR competencies and core tasks of CSR implementation in a business context. The first research question of this paper therefore is: 1) Which managerial CSR competencies identified in the extant literature can be connected to CSR managers' core tasks in CSR implementation? An additional research question has to be raised to answer this question, because competencies get more meaningful when related to the context in which they are performed (Mulder et al., 2005). The second research question is: 2) What core tasks of CSR implementation can be identified for CSR managers operating in a business context? Since this article concentrates on the business context, in the remainder of this article sustainability and CSR are used interchangeably to characterize the ongoing process within organizations to realise sustainable business practices.

This research is relevant from a scientific point of view because it is interesting to know which competencies really matter in CSR implementation practices, as empirical findings about what is required of the sustainability professionals are still limited (Hesselbarth and Schaltegger, 2014). Furthermore, linking competencies with core tasks makes it possible to operationalise competencies in a more concrete way, which is necessary as indicated by Adomßent et al. (2014). On the basis of several articles within the framework of Education for Sustainable Development (ESD), they concluded that it is still necessary to operationalise competencies for measurement (i.e. assessment instruments) and educational purposes (i.e. education programmes). The latter is also important from a managerial point of view. The identified competencies, accompanied by core tasks, may enhance human resource practices (e.g. selection, development, assessment) and the development of these practices in the business (education) context.

The paper is structured as follows: first a theoretical framework for CSR competencies is presented, followed by a method section in which the methods applied are elaborated upon. Finally, the findings, conclusion and discussion are presented.

\section{Theoretical framework}

In this section the theoretical underpinnings concerning competencies are presented. The first part concerns itself with competencies in general while the second part discusses competencies specifically applicable to CSR.

\subsection{Competencies}

In education, as well as in the corporate world, the term competencies is used as a vehicle for communicating about performance and learning processes of individuals (Mulder, 2001). Boyatzis (1982) and McLagan (1989) were the first to link the practice of human resource management to development in organisations. Competencies are seen as useful (e.g., Dubois and Rothwell, 2004; Lievens et al., 
2004), since they can be utilized in strategic workforce planning, selection, training and development, performance management, succession planning, and motivation and rewarding. Using competencies in organisations has benefits for both organisation and employee. The former is able to align its strategic goals with the goals of the employees, and the latter experiences more transparency (Mulder, 2001). Nonetheless, the concept of competence has been applied in widely differing ways in different countries (Gonczi, 1994), in different disciplines, and at different times. It is this widespread use that is one of the major pitfalls in working with competencies (Biemans et al., 2004). In order to fully understand what is meant by competence in this study, the researchers think it is necessary to make abundantly clear how to define the concept.

One can distinguish three main conceptualisations of competence: behaviouristic, generic and holistic (Biemans et al., 2004; Sandberg, 2000). In the behaviouristic conceptualisation competencies are described as observable behaviours (no attention is paid to the individuals' input, only the output is studied) associated with the completion of each small task (Gonczi, 1994). In the generic conceptualisation of competence, which was formulated as a response to the behaviouristic approach, competencies are personal qualities (character traits included) that distinguish average performers from excellent performers (Eraut, 1994). While the context is taken into account at first, through the identification (critical incidents), it gets lost again because this approach attempts to arrive at generic descriptions. Currently, Biemans et al. (2004) indicate that most interpretations of competencies are derived from the holistic conceptualisation. Within the holistic tradition, the concept of competence is defined as follows: "Competence is the integrated performance-oriented capability of a person or an organisation to reach specific achievements. These capabilities consist of clusters of knowledge structures and also cognitive, interactive, affective and where necessary psycho-motoric skills, and attitudes and values, which are conditional for carrying out tasks, solving problems and effectively functioning in a certain profession, organisation, position and role" (Mulder, 2001, p.76). Hodkinson and Issitt (1995) distinguish two dimensions of holism. The first dimension concerns the integration of knowledge, skills and attitudes that are meaningful to someone who is (becoming) a practitioner. The second dimension of holism relates to the interrelatedness with the context; competencies can only be displayed in a context by taking core tasks or roles into account.

The aforementioned holistic conceptualisation of competence is adopted in this article, because this conceptualisation is based on the observation that competence only acquires meaning within a certain context, where professionals interact with one another. Furthermore, it acknowledges that competence is related to the notion of situated cognition: "Knowledge is situated, being in part a product of the activity, context, and culture in which it is developed and used" (Brown, Collins and Duguid, 1989, p. 32). The conceptualisations of competence in the behaviouristic and generic traditions fall short in addressing the developmental and situated nature of professional practice (Billett, 1994), and situated professionalism (Mulder, 2014). Mulder et al. (2005) have emphasised the importance of analysing meaningful combinations of core tasks before competencies can be identified or selected; said core tasks represent the situation in which the competencies are put into practice. Taking core tasks as a starting point ensures that the situation (i.e. the job and organisation) in which the competencies are to be applied is taken into account. In this approach, competence modelling consists first of a task analysis (from the perspective of the work that has to be done to ensure the connection with the situation) and second a competence analysis (from the perspective of the worker who has to do the work) (Sandberg, 2000). This corresponds with what Cheetham and Chivers (1996) have called the functional approach.

\subsection{CSR competencies}


Over the past few years, individual competencies for sustainable development have received increasing attention in sustainability literature. Significant progress has been made in conceptualising competencies for sustainable development, predominantly in the world of education (e.g., Barth et al., 2007; De Haan, 2010; Wiek et al., 2011). Steps have been taken in the corporate world as well, Willard et al. (2010) provides us with an overview of the competencies of sustainability managers. Within the educational tradition, two recent studies should be singled out for their empirical approach. In the first place, the study by Rieckmann (2012). He identified three important competencies (labelled as key competencies) for higher education: systemic thinking and handling of complexity, anticipatory thinking, and critical thinking. The significant value of this paper is the way it utilises its empirical basis (i.e. by questioning international experts in the field of SD) to achieve international agreement in the debate concerning the most important key competencies for SD. Secondly, the work of Hesselbarth and Schaltegger (2014). On the basis of MBA alumni's experiences, they empirically linked sustainability competencies with situated duties and activities. They created a so-called competency matrix for change agents in sustainability, in which they propose a structure of basic components for postgraduate education in sustainability management. To complement and advance on this strand in the literature, this research introduces and applies a method for providing empirical evidence on CSR competencies from the perspective of managers undertaking CSR implementation practices.

In this study competencies are linked to core tasks of a job, while practitioners (CSR managers) provide the empirical basis; the situatedness is taken into account. In this way, competencies might grow more meaningful (according to Mulder, 2014) and that, in turn, might lessen the differences of opinion about the proper interpretation of the competencies required for sustainability. The aim of this article therefore - as the introduction already stated - is to relate CSR (key) competencies to the core tasks of CSR managers in everyday practice, in order to get a better sense of the desired competencies with the aim of increasing meaningfulness and doing away with misinterpretations.

Dentoni et al. (2012) made use of existing frameworks for SD and CSR competencies. They used De Haan (2010) and Wiek et al. (2011) as starting points, complemented by sets of SD competencies reported by Ellis and Weekes (2008), Mogenson and Schnack (2010), Schnack (1996) and Wilson et al. (2006). From this they composed a list of seven competencies for sustainability. This list is a comprehensive overview of SD competencies up to 2011 and was taken as a starting point for this study. But neither the list by Dentoni et al. (2012), nor the lists sourced from other authors (i.e. De Haan, Wiek et al.) view competencies in relation to the tasks or job duties of sustainability managers in professional practice. This stems from the predominantly educational purposes and backgrounds of said sets of competencies.

Dentoni et al. (2012) composed a framework consisting of seven competencies required for professionals who are actively involved in dealing with sustainability in their work environment:

1. Systems thinking competence: the ability to identify and analyse all relevant (sub)systems across different domains (people, planet, profit) and disciplines, including their boundaries. Systems thinking competence is the ability to understand and reflect upon the interdependency of these (sub)systems, including cascading effects, inertia, feedback loops and accompanying cultures (Wiek et al., 2011).

2. Embracing diversity and interdisciplinarity competence: the ability to structure relationships, spot issues, and recognise the legitimacy of other viewpoints in business decision making processes; be it about environmental, social and/or economic issues. It is the ability to involve all stakeholders and to maximise the exchange of ideas and learning across different groups (inside and outside the organisation) and different disciplines (De Haan, 2010; Ellis and Weekes, 2008; Wilson et al., 2006). 
3. Foresighted thinking competence: the ability to collectively analyse, evaluate, and craft "pictures" of the future in which the impact of local and/or short term decisions on environmental, social and economic issues is viewed on a global/cosmopolitan scale and in the long term (Wiek et al., 2011).

4. Normative competence: the ability to map, apply and reconcile sustainability values, principles and targets (Wiek et al., 2011).

5. Action competence: the ability to actively involve oneself in responsible actions for the improvement of the sustainability of social-ecological systems (De Haan, 2010; Mogensen and Schnack, 2010; Schnack, 1996).

6. Interpersonal competence: the ability to motivate, enable, and facilitate collaborative and participatory sustainability activities and research (Wiek et al., 2011).

7. Strategic management competence: the ability to collectively design projects, implement interventions, transitions, and strategies for sustainable development practices. This domain involves skills in planning (e.g., design and implement interventions), organising (arranging tasks, people and other resources), leadership (inspiring and motivating people) and control (e.g., evaluating policies, programmes and action plans) (De Haan, 2010; Wiek et al., 2011).

The following section describes the empirical analysis methods used in this research.

\section{Methods}

To answer the research questions, existing interview data from a prior research project was used. Analysing existing data for another purpose - i.e. secondary data analysis - involves pursuing a research interest which is distinct from that of the original work; be it a new research question or an alternative perspective on the original question (Hinds et al., 1997).

In this case, the stated goal of the prior research project was learning how companies engage with stakeholders - such as NGOs or governments (Selsky and Parker, 2005) - and integrate knowledge of sustainable development into the organisation (Veldhuizen et al., 2013). Within the context of this prior project, the interviews described how managers undertook CSR activities in a multi-stakeholder collaboration context; said project focused on the company involvement in cross-sector partnerships within the framework of sustainability. The analysis put forward in this article, however, focuses on the core tasks of individual professionals involved in the implementation of sustainability. The fact that stakeholder involvement is crucial for working on CSR challenges has already been pointed out in the theoretical section by referring to Peterson (2009); social responsibility implies responsiveness to the expectations of stakeholders. All in all, the reutilisation of the existing interview data for pursuing answers to other, albeit closely related, research questions was deemed legitimate. It adheres to what has been called a new perspective focus (Heaton, 2002).

Heaton (2002) summarises four methodological and ethical concerns to be taken into consideration when utilising secondary data analysis. The first issue concerns compatibility of the data. To what extent are the data amenable to the goals of the secondary analysis? In this case, all of the interviews were aimed at the analysis of organisational drivers for sustainable development. It was therefore considered to be compatible. The second issue reported by Heaton (2002) concerns the position of the secondary analyst. The requirement that was formulated to satisfy this issue is that the secondary analyst has access to the primary data. In the current study, one of the analysts involved in the secondary data analysis was also involved in collecting and analysing the primary data for the original study. The third issue concerns the transparency with which the primary data were gathered. In this study, the design, methods, and issues involved are fully reported on so as to be as transparent as possible. Finally, Heaton (2002) brings forward the ethical issue. Where sensitive data is involved, to 
what extent does secondary analysis violate the contract made between the subjects and the primary researchers? In this case the topic of the interviews was sustainability as well, so in that sense the contract is not deemed to have been violated.

The original research was based on case studies. Cases were selected on the basis of theoretical sampling (see Veldhuizen et al., 2013 for more details on sampling and criteria). The case study method is also appropriate for this current study because the context in which the managers operate is crucial to the tasks they perform and consequently to the competencies they need (Yin, 2003). Furthermore, the case study method lends itself to theoretical development (Yin, 2003). The nature of the study is qualitative, in the sense that in-depth interviews of four managers were used for this research. This research has an explorative nature because, to the knowledge of the researchers, it is the first time the theoretical (key) competencies are defined in relation to practical core tasks of CSR implementation.

\subsection{Sample Selection \& Data Collection}

As part of the prior project from which the interviews constituting the database for this research are taken, between 2011 and early 2012 researchers questioned CSR managers of four of the fifty largest global agri-food MNE's. The agri-food business is a primary example of a sector where sustainability is important, given its role in food-related health crises (European Commission, 2001) and the enhancement of food safety (Hamann et al., 2012). Companies in the agri-food sector increasingly attempt to meet the expectations of their stakeholders (customers, governmental organisations, society at large) (Dentoni et al., 2012) in order to secure and enhance their license to operate (Blok et al., 2013; cf. Gunningham et al., 2004).

While in the prior research the four companies involved in CSPs were purposely selected (Veldhuizen et al., 2013), in this study it is the CSR managers that are analysed - rather than their companies - since this study's unit of analysis is the individual rather than the organization. The cases of the four managers are comparable based on the following three parameters: 1) all companies operate in the same industry (food manufacturers buying raw agricultural products); 2) all companies are comparable in size - being large multi-nationals procuring similar agricultural products from developing countries and emerging economies - and facing similar sustainability problems (similar in terms of global scale and complexity of the issues at hand); and 3) all CSR managers work at the decision-making European headquarters of their respective companies; all of which are based in the Netherlands.

The interviews were held with CSR managers (responsible for sustainability and CSR), were semi-structured in nature, and focused on understanding how they dealt with multiple stakeholders in the process of CSR implementation. Indirect questioning techniques were utilised to learn as much as possible from the subjects, while at the same time attempting to minimise social desirability bias (Fisher, 1993). The managers were asked to: "describe a set of CSR initiatives undertaken by themselves as their companies' CSR representatives with stakeholders over time, both within and outside CSP for SD".

\subsection{Data analysis}

Although multiple cases are used, it is not the aim of this study to compare said cases. The cases are used to describe the tasks and activities of the CSR managers in their real-life context. The data gathered in the four cases are analysed by means of a descriptive method (Yin, 2003).

The analysis of the interview data involved three steps and consisted of a combination of inductive and deductive methods. All steps were undertaken with three researchers (in each step the same researchers were involved) in order to establish intersubjectivity. 
The first step consisted of the identification of core tasks. As explained above, a core task is defined as an important meaningful task in practice (Mulder et al., 2005). Core tasks undertaken in the sustainability initiatives were identified from the raw data in an inductive way. The first step was marking those excerpts from each interview that represented relevant process steps and activities in moving towards sustainability. These excerpts were subsequently labelled; the labels emerged bottom up while selecting the excerpts. Initially, each researcher examined the interview transcripts individually and, subsequently, identified excerpts and coded these excerpts with labels (open coding; Glaser and Strauss, 1967). Then the different lists of excerpts and accompanying labels were compared by the group of researchers as a whole and integrated into one list by means of axial coding (Glaser and Strauss, 1967); eventually ending up with a list of core tasks. Different rounds of coding were needed to attain sufficient intersubjective agreement (Glaser and Strauss, 1967). The result was a list of 19 core tasks to be explored and have their interrelationship examined. This resulted in four sets of core tasks arranged in chronological order: I) Orientation, II) reaching common ground, III) performing pilot projects, and IV) embedding results.

The second step was to identify labels for the competencies in order to make them, as formulated within the theoretical framework, less abstract. Based on the description of the competencies by Dentoni et al. (2012), and an existing questionnaire based on those same competencies (Lans et al., 2014), the seven competencies were provided with labels representing underlying performance criteria. This resulted in a total set of 70 labels for all CSR competencies (see appendix A). This step had a deductive character; the theory-based competence descriptions are rendered more concrete by means of these labels.

In the third and final step, the outputs of step 1 and 2 were matched. In practice this meant that the relationship between the sets of core tasks (step 1) and the competencies (step 2) were assessed. This relationship was assessed based on the overlap of both sets of concrete labels. Each researcher initially examined the relationship between the labels of the competencies and labels of the core tasks on his/her own. Subsequently, the similarities and differences were identified by the researchers as a group. Since coding relations between core tasks and competencies is mainly interpretative work (Glaser and Strauss, 1967), three rounds of discussion were needed to attain intersubjective agreement. The percentage of labels that straddled both constructs was called the overlap (see table 3 ). If more than $50 \%$ of the labels of the competencies and the core tasks showed overlap, there was considered to be a relationship between competence and core task. The percentage used is relatively low, owing to the explorative character of this study, but is considered appropriate at this stage.

\section{Findings}

The findings section is divided into two parts (respectively, the results of step 1 and 2) after which these two parts are integrated (step 3). The first part concerns the core activities of implementing CSR divided among four phases. In table 1 , the four sets of core tasks are shown alongside the individual core tasks. These sets of core tasks are: I) Orientation, II) Reaching common ground, III) Performing pilot projects and IV) Embedding results. Each set consists of three to six core tasks and each core task is described in the table.

\begin{tabular}{|l|l|}
\hline Set of core tasks & Core tasks \\
\hline I. Orientation & 1. Sustainability thinking \\
& 2. Analysing systems \\
& $3 . \quad$ Identifying consumer needs \\
\hline
\end{tabular}




\begin{tabular}{|l|l|}
\hline & 4. Willingness to change \\
& 5. Weighing stakeholders \\
& 6. Strategic decision making \\
\hline II. Reaching common ground & 7. Initiating changes \\
& 8. Building openness and trust \\
& 9. Sharing objectives \\
& 10. Balancing interests \\
& 11. Operational decision making \\
\hline III. Performing pilot projects & 12. Collaborating \\
& 13. Knowledge sharing and integration \\
& 14. Project management \\
& 15. Supply chain orientation \\
& 16. Disseminating output \\
\hline IV. Embedding results & 17. Creating project ownership / empowering internal change agents \\
& 18. Integrating approaches \\
& 19. Marketing \\
\hline
\end{tabular}

The second part of the results consists of the competencies and accompanying labels. In step 2, for each competence between 5 and 19 labels were identified. Appendix A shows the entire set of labels. In table 2, the accompanied core tasks are shown per competence (i.e. systems thinking competence) if the overlap between the labels representing competencies and the labels representing core tasks was $50 \%$ or more.

\begin{tabular}{|c|c|c|c|c|}
\hline Competence & $\begin{array}{l}\text { Core tasks (number of core task } \\
\text { set) }\end{array}$ & 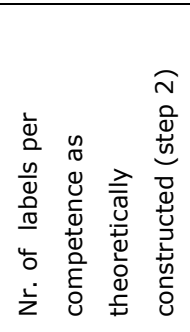 & 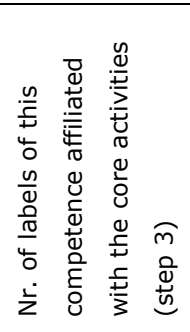 & 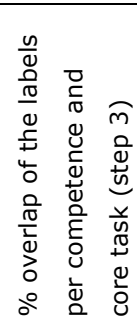 \\
\hline \multirow{2}{*}{$\begin{array}{l}\text { Systems thinking } \\
\text { competence }\end{array}$} & 2. Analysing systems (I) & 12 & 12 & $100 \%$ \\
\hline & 15. Supply chain orientation (III) & 12 & 12 & $100 \%$ \\
\hline $\begin{array}{l}\text { Foresighted thinking } \\
\text { competence }\end{array}$ & 3. Identifying consumer needs & 10 & 2 & $20 \%$ \\
\hline Normative competence & 1. Sustainability thinking & 9 & 1 & $11 \%$ \\
\hline \multirow{6}{*}{$\begin{array}{l}\text { Embracing diversity } \\
\text { and interdisciplinarity } \\
\text { competence }\end{array}$} & 4. Willingness to change (I) & 7 & 4 & $57 \%$ \\
\hline & 5. Weighing stakeholders (II) & 7 & 7 & $100 \%$ \\
\hline & 10. Balancing of interests (II) & 7 & 7 & $100 \%$ \\
\hline & $\begin{array}{l}\text { 13. Knowledge sharing and } \\
\text { integrating (III) }\end{array}$ & 7 & 5 & $71 \%$ \\
\hline & $\begin{array}{l}\text { 8. Building openness and trust } \\
\text { (III) }\end{array}$ & 7 & 7 & $100 \%$ \\
\hline & 18. Integrating approaches (IV) & 7 & 6 & $86 \%$ \\
\hline Interpersonal & 9. Sharing objectives (II) & 8 & 7 & $88 \%$ \\
\hline
\end{tabular}




\begin{tabular}{|c|c|c|c|c|}
\hline \multirow[t]{3}{*}{ competence } & 10. Balancing of interests (II) & 8 & 6 & $75 \%$ \\
\hline & $\begin{array}{l}\text { 8. Building openness and trust } \\
\text { (III) }\end{array}$ & 8 & 8 & $100 \%$ \\
\hline & $\begin{array}{l}\text { 17. Creating project } \\
\text { ownership/empowering internal } \\
\text { change agents (IV) }\end{array}$ & 8 & 4 & $50 \%$ \\
\hline \multirow[t]{2}{*}{ Action competence } & 7. Initiating changes (II) & 5 & 5 & $100 \%$ \\
\hline & $\begin{array}{l}\text { 11. Operational decision making } \\
\text { (II) }\end{array}$ & 5 & 4 & $80 \%$ \\
\hline \multirow{2}{*}{$\begin{array}{l}\text { Strategic management } \\
\text { competence }\end{array}$} & 6. Strategic decision making (I) & 19 & 9 & $51 \%$ \\
\hline & 14. Project management (III) & 19 & 16 & $84 \%$ \\
\hline
\end{tabular}

Table 2 shows us that the labels of five competencies show sufficient overlap with labels of core tasks. These competencies are: Systems thinking, Embracing diversity and interdisciplinarity, Interpersonal, Action and Strategic management. The competencies Normative and Foresighted thinking are not linked to core tasks during the analysis. Except for Action, all competencies are deemed necessary in more than one or even more than two sets of core tasks. In the first set of core tasks (Orientation) three competencies are identified as necessary: Systems thinking, Embracing diversity and interdisciplinarity, and Strategic management. In set II (Reaching common ground), there are also three competencies that are identified as necessary for performing the core tasks: Embracing diversity and interdisciplinarity, Interpersonal, and Action. In set III (Performing pilot projects), there are even four competencies that are considered necessary: Systems thinking, Embracing diversity and interdisciplinarity, Interpersonal, and Strategic management. In set IV (Embedding results), two competencies are considered necessary: Embracing diversity and interdisciplinarity, and Interpersonal. In all sets the Embracing diversity and interdisciplinarity competence is viewed as vital to the core tasks of implementing CSR; table 3 provides an overview. In this table the relationships between the competencies and the sets of core tasks is shown. Where competencies were related to one or more of the core tasks in the sets of core tasks, a mark was placed in the corresponding box.

\begin{tabular}{|c|c|c|c|c|}
\hline & 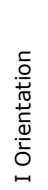 & 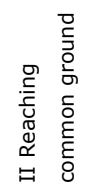 & 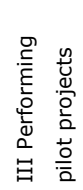 & 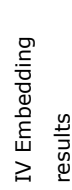 \\
\hline Systems thinking competence & $\mathrm{X}$ & & $\mathrm{X}$ & \\
\hline Embracing diversity and interdisciplinarity competence & $\mathrm{X}$ & $\mathrm{X}$ & $\mathrm{X}$ & $\mathrm{X}$ \\
\hline Interpersonal competence & & & $\mathrm{X}$ & $\mathrm{X}$ \\
\hline Action competence & & $\mathrm{X}$ & & \\
\hline Strategic management competence & $\mathrm{X}$ & & $\mathrm{X}$ & \\
\hline
\end{tabular}

Reading the content of table 3, it illustrates clearly that the this study does not identify the competencies Normative and Foresighted thinking as necessary for the realisation of CSR and that Embracing diversity and interdisciplinarity is the one that is needed in all sets of core tasks for the realisation of CSR. 
Furthermore, table 3 shows that when applying the 50\% rule, the following core tasks are excluded for a lack of overlap: sustainability thinking (only 11\%), identifying consumer needs (only 20\%), collaborating (no overlap at all), disseminating output (no overlap at all) and marketing (no overlap at all). This does not mean that those core tasks are unimportant; it just means that they do not relate to the competencies as put forward by theory. This indicates that other competencies need to be identified, because the current ones cannot be linked to these core tasks.

\section{Discussion}

Within the context of this research, the competencies Foresighted thinking and Normative were not recognised in the CSR practices of the four CSR managers. This does not mean that these competencies are totally unimportant; both Rieckmann (2012) and Hesselbarth and Schaltegger (2014) provide empirical evidence for both competencies (or comparable constructs). The results of this study only indicate that those competencies are not related to the core tasks of the four CSR managers under analysis.

In other words, within the specific context of these CSR managers, Foresighted thinking does not appear to be necessary anymore. This could lead to the interpretation that Foresighted thinking is only necessary at the point in time when the decision to start working on sustainability is taken by the board of directors, while for other people within the organisation (CSR managers in this case) it is not necessary, from an organisational point of view, to think foresightedly. This possible explanation would be consistent with what is depicted by Maon et al. (2008): each phase of CSR implementation (i.e. sensitize, unfreeze, move and refreeze) demands different activities and qualities from managers and organisations. Following this line of reasoning, Foresighted thinking could be relevant in the starting (sensitize) phase and lose its importance in the other phases (unfreeze, move and refreeze) where the analysed managers currently reside.

The Normative competence also went unrecognised in the specific setting of the analysed managerial CSR practices. Sustainability is undeniably a normative concept, as it does not describe the world as it is but as it should be. In the Normative competence, values, principles, goals and targets are negotiated and it includes such broad concepts as integrity, equality and justice (Wiek et al., 2011). In this respect, normative competence concerns itself with the way companies should operate. According to this view on normative competence, a plausible interpretation of this result is that managers do not recognise the Normative competence in their CSR practice because it has been internalized in their behaviour. Another, yet still plausible, interpretation is that the apparent absence of normative competence in the dataset may indicate structurally low levels of normative competence within the selected business context. This, in turn, could explain some of the conflicts between companies and NGOs with regards to value frames and trade-offs between ecological and economic interests (Peterson, 2009). In this respect, one could argue that these companies are not acting in an ethical fashion. This could, for instance, be due to a strong focus on profit maximisation. In this respect, these findings could be seen as confirmation of the classical view of the firm as non-ethical, or of the fact that these competencies are not necessary (anymore) in the phase the participating companies find themselves in.

Action competence is only recognised in relation to the second set of core tasks (reaching common ground). This could be seen as a surprising result because one would expect that the action competence might be important while performing pilot projects (III) as well. Action competence, however, means to actively involve oneself in responsible actions for the improvement of the sustainability of social-ecological systems (De Haan, 2010; Ellis and Weekes, 2008; Mogensen and Schnack, 2010). Because action competence (with labels such as: pro-activeness in decision making, 
taking responsibility, and perseverance of goals) concentrates on the personal involvement and personal actions of a CSR manager (De Haan, 2010) and not on the activity of other members of the company (e.g., line-managers, support staff). This may explain why action competence is in fact important for the second set of core tasks, namely to reach common ground. This implies that CSR managers initiate action and bring parties together when they deem it necessary.

Strategic management competence and Systems thinking competence are both identified as important to the set of core tasks Orientation (I) and Performing pilot projects (III). This can be explained by the fact that management in this first phase has to be performed mainly outside of the company (i.e. with stakeholders) and be seen within the larger context. The third set of core tasks concerns mainly internal (strategic) management. CSR managers' systems thinking focuses mainly on the product or process level. For example, systems - as described by Wiek et al. (2011) - are abstract by nature, whereas in the practice of the CSR manager systems equate to products. Both competencies are needed at two different levels which implies differing operationalisations of these competencies in relation to the different sets of core tasks.

Furthermore, Interpersonal competence is considered important in the last two sets of core tasks (performing pilot projects and embedding results). It turns out that convincing one's company's employees and managers to participate in a pilot project is of vital importance. And the execution of that core task depends heavily on the interpersonal competencies of CSR managers. After convincing the employees and management, it is important that CSR managers keep sustainability on the agenda and embed the results in daily practice. Interpersonal competencies turn out to be very important in this set of core activities as well.

Finally, the results suggest that the Embracing diversity and interdisciplinarity competence is the one that is identified as necessary for all sets of core tasks. It is relevant to all sets because the diversity of stakeholders and their values and opinions are important while also being subject to change. So, it is necessary to constantly review stakeholder opinions (internally and externally) and take those considerations into account. Interdisciplinarity is also present in all sets of core tasks. CSR managers have to cooperate with people representing different disciplines in each set of core tasks; with NGOs in the first (Orientation) phase, for example, and in later stages with representatives of internal company disciplines (in project teams with representatives from different departments, for example). In the research by De Haan (2010) interdisciplinarity is merely considered in terms of topics (poverty or economics) that have to be analysed and evaluated in the past and present. When operationalising this competence in the context of CSR managers, it mainly comes down to working with people with a different (disciplinary) background. CSR managers constantly work with groups of people from a wide range of disciplines and the composition of these groups varies in accordance with different sets of tasks. Rieckmann (2012) also confirms the significant importance of interdisciplinary work, empathy, and change of perspective; although not as one of the three most important key competencies. This might be explained by the different empirical bases (i.e. education and corporate) on which the conclusions were drawn.

It is shown that each verified competence has its own role to play in a particular set of tasks. The operationalisation of the same competence differs per set of core tasks, thus giving more in-depth understanding of what CSR competencies encompass. This makes the competencies more meaningful, comprehensible in practice and less exposed to ambiguous interpretations, which is beneficial for training and assessment purposes like ESD (Adomßent et al., 2014).

Follow-up research would necessarily need to uncover which competencies are necessary to underpin those core tasks that fell out of this study's analysis. This concerns the core tasks: 
sustainability thinking, identifying consumer needs, collaborating, disseminating output, and marketing. It should be possible, by means of interviews, to learn more about these core tasks and to identify the competencies they desire. This overview of competencies underpinning core tasks for implementing sustainability is therefore not complete yet. One would expect to find a competence like communicating with stakeholders outside the own organisation (O'Riordan and Fairbrass, 2013).

What do the outcomes of this study mean for (future) CSR managers; how can they develop these competencies? For them, it is important to receive feedback from other employees and reflect on their practical experiences so as to learn together from dealing with and solving CSR challenges. In the first place, the situational/contextual aspect is very important for learning (Billett, 1994), so general approaches for teaching these competencies are less desirable. Secondly, it is extremely difficult to approach the complexity of sustainability challenges in educational settings, although research shows that higher education is making great strides towards implementing education for sustainable development (Rieckmann, 2012; Wals, 2014; Lambrechts et al., 2013). Higher education will provide students with a necessary and firm basis through the use of service learning, for example. It remains, however, necessary to implement (learning) activities in (management) practice. Learning sustainability or CSR is a continuous and collective (learning) process (cf. Blok, 2013) and those managers that are already professionals will have to develop themselves in this area. The competencies required are too complicated to develop "on the fly". Managers need discussion and feedback, to really develop and improve these competencies.

The research described in this article is an attempt to approach CSR competencies from a situated conceptualisation of competence. The next step in research would be to actually test how the competencies and core tasks relate to each other through a more quantitative approach, while the relationships that this study revealed could be tested more broadly.

The research set-up and approach chosen in this study have their limitations; the first set of limitations relates to the secondary data analysis. In the first place, although the conditions - as set by Heaton (2002) - are met, the very nature of secondary data analysis leaves it particularly susceptible to criticism and it would be most effective when combined with other approaches (Smith, 2008). In this particular case, the data were gathered with another aim, consequently there was no chance to ask further questions on the particular topic of this article and it remains unclear whether all information that the subjects had to offer about the core tasks in relation to CSR was shared. Nevertheless, one can consider this a useful exploration of introducing and applying a method for operationalising competencies and for gauging what competencies are necessary for which CSR core tasks in management practice. Secondly, the context in which the managers under analysis operate is highly specific since the four managerial cases have key common characteristics. Thirdly, uncovering managers' competencies necessary for realising CSR is considered to be quite difficult (cf. Van Kleef and Roome, 2007); because asking managers for these competencies mostly ends in every competence being deemed important. Connecting the competence with core tasks and applying an indirect analysis prevents this problem. Where it comes to the purpose of operationalising the competencies, the set-up of this research appears to be sufficient and the results of this study should be seen as setting the research agenda. It is important to test the operationalisation on a larger scale, though. In relation to this, the researchers feel the choice to work with $50 \%$ overlap was justified. The purpose of this article, as mentioned before, was to explore how competencies and core tasks relate to each other, and in the opinion of the researchers a $50 \%$ overlap is considered sufficient to demonstrate a relationship.

The second set of limitations relates to case studies. The most important shortcoming of a case study method is the seeming lack of generalisability of the outcomes (Yin, 2009). This study incorporates 
four cases (i.e. CSR managers) and that is a relatively small number. The extent to which the results can be generalised is to be considered limited. The results are especially valid for managers working in agrifood companies that took the decision to effect CSR (and therefore already appointed CSR managers, for example), and are in the phase of actually working on pilot projects to implement it (unfreeze stage; Maon et al. 2009). Another pitfall of the case study approach is how to ensure the consistency in the findings. To maximise robustness two measures were taken. In the first place, the interview data were collected by means of semi-structured interviews, so they were comparable to a large extent. And secondly, because multiple researchers independently coded the interview data and subsequently met and came to a consensus on the emerging codes and categories, the reliability of the findings was increased (Baxter and Jack, 2008).

Finally, the role of CSR managers was central to this study. But, as the core tasks already show, the CSR managers are not the only persons involved in the implementation of CSR. The CSR managers could be identified as the "change agents" of Hesselbarth and Schaltegger (2014), but these professionals need to involve other employees within their organisations as well (in projects, for example). They are the ones who have to bring about change and ensure that CSR is an ongoing (and collective) learning process, which should eventually involve all company employees. In further research, it remains to be seen to what extent other employees within organisations need competencies and how these competencies are distributed among different groups of employees. Maybe it would be possible to identify specific competencies for specific sets of CSR core tasks and groups of employees within organisations. This would make the operationalisation of the competencies even more concrete.

\section{Conclusions}

To contribute to the theory and practice of CSR and competencies, two research questions guided this study. The first research question of this paper was: 1 ) Which managerial CSR competencies identified in the extant literature can be connected to CSR managers' core tasks in CSR implementation? To answer this question, an additional research question was raised, because competencies are more meaningful in relation to the core tasks (situation) in which they are performed. 2) What core tasks of CSR implementation can be identified for CSR managers operating in a business context?

Knowing that the results of research question 2 are conditional upon the results of research question 1 , the conclusion to research question 2 is presented first. In total, four sets of core tasks were identified while analysing the transcripts of the interviews with CSR managers: I) orientation (6 core tasks), II) reaching common ground (5 core tasks), III) performing pilot projects (5 core tasks) and IV) embedding results ( 3 core tasks). These core tasks represent the daily tasks of CSR managers of companies that have been working on CSR for some years. Related to the first research question, the results suggest that the following competencies are to be recognised in relation to the sets of core tasks: Systems thinking, Embracing diversity and interdisciplinarity, Interpersonal competence, Action competence and Strategic management. These competencies all have a link with one or more sets of core tasks. Linking competencies with core tasks contextualises CSR competencies in CSR management practices and provides empirical evidence of the theoretically identified competencies.

The aim of this article was to explore which competencies would relate to CSR core tasks as identified in CSR managerial practice. This contributes to the literature by refining the existing CSR competencies theory with an empirical method that identifies the core tasks for CSR implementation while finding its basis in managerial practice. Future research at the individual level could benefit from applying this method to identify sets of relevant competencies and core tasks in different and broader contexts. Furthermore, the list of competencies in relation to core tasks has practical advantages for both 
corporate and educational practices. Connecting the competencies to core tasks makes these competencies more meaningful and opens up possibilities of operationalising these competencies. For both the educational context (development and assessment) and the management context (especially development) this gives concrete input for learning trajectories (i.e. service learning, peer feedback).

\section{References}

Adomßent, M., Fischer, D., Godemann, J., Herzig, C., Otte, I., 2014. Emerging areas in research in higher education for sustainable development - management education, sustainable consumption and perspectives from Central and Eastern Europe. Journal of Cleaner Production 62, 1-7.

Aguinis, A., Glavas, H., 2012. What We Know and Don't Know About Corporate Social Responsibility: A Review and Research Agenda. Journal of Management 38 (4), 932-968.

Barth, M., Godemann, J., Rieckman, M., Stoltenberg., U., 2007. Developing key competences for sustainable development in higher education. International Journal of Sustainability in Higher Education 8, 416-430.

Baumgartner, R.J., Winter, T., 2013. The Sustainability Manager: A Tool for Education and Training on Sustainability Management. Corporate Social Responsibility and Environmental Management. DOI: 10.1002/csr.1313.

Baxter, P., Jack, S., 2008. Qualitative Case Study Methodology: Study Design and Implementation for Novice Researchers. The Quantitative Report 13 (4), 544-559.

Biemans, H. J. A., Nieuwenhuis, L., Poell, R., Mulder, M., Wesselink, R., 2004. Competence-based VET in the Netherlands: backgrounds and pitfalls. Journal of Vocational Education and Training 56 (4), 523-538.

Billett, S., 1994. Situated Learning - a workplace experience. Australian Journal of Adult and Community Education 34 (2), 112-130.

Blok, V., 2013. The Power of Speech Acts: Reflections of performative concepts of ethical oaths in economics and business. Review of Social Economy 71 (2), 187-208.

Blok, V., Sjauw-Koen-Fa, A., Omta, O., 2013. Effective Stakeholder Involvement at the Base of the Pyramid: The case of Rabobank. International Food and Agribusiness Management Review 16A, 39-44.

Boyatzis, R. E., 1982. The competent manager: a model for effective performance. Wiley, New York.

Brown, J.S., Collins, A., Duguid, S., 1989. Situated cognition and the culture of learning. Educational Researcher 18 (1), 32-42.

Cheetham, G., Chivers, G., 1996. Towards a holistic model of professional competence. Journal of European Industrial Training 20 (5), 20-30. 
Dahlsrud, A., 2008. How Corporate Social Responsibility Is Defined: An Analysis of 37 Definitions. Corporate Social Responsibility and Environmental Management 15 (1), 1-13.

De Colle, S., Henriques, A., 2013. The Paradox of Corporate Social Responsibility Standards. Journal of Business Ethics. DOI 10.1007/s10551-013-1912-y.

De Haan, G., 2010. The development of ESD-related competencies in supportive institutional frameworks. International Review of Education 56, 315-328.

Dentoni, D., Blok, V., Lans, T., Wesselink, R., 2012. Developing Human Capital for Agri-Food Firms' Multi-Stakeholder Interactions. International Food and Agribusiness Management Review 15, 61-68.

Dubois, D., Rothwell, W., 2004. Competency-Based or a Traditional Approach to Training? ProQuest Education Journals 58 (4), 46-58.

Dunphy, D., Griffiths, A., Benn, S., 2003. Organisational Change for Corporate Sustainability. Routledge, London.

Ellis, G., Weekes, T., 2008. Making sustainability 'real': using group-enquiry to promote education for sustainable development. Environmental Education Research 14, 482-500.

Eraut, M., 1994. Developing professional knowledge and competence. Falmer Press, London.

European Commission (2001). Promoting a European framework for corporate social responsibility. Green paper. European Commission.

Fisher, R.J., 1993. Social Desirability Bias and the Validity of Indirect Questioning. Journal of Consumer Research 20, 303-315.

Freeman, R.E., 2010. Strategic Management: A Stakeholder Approach. Pitman, Boston.

Glaser, B., Strauss, A.L., 1967. The Discovery of Grounded Theory: Strategies for Qualitative Research. Aldine Publishing Company, Chicago.

Gonczi, A., 1994. Developing a competent workforce. National Centre for Vocational Education Research. Adelaide.

Gunningham, N., Kagan, R.A., Thornton, D. 2004. Social License and Environmental protection: Why businesses go beyond compliance. Law \& Social Inquiry 29 (2) 307-341.

Hamann, R., Giamporcaro, S., Johnston, D., 2011. The role of business and cross-sector collaboration in addressing the 'wicked problem' of food insecurity. Development Southern Africa 28 (4), 579-597.

Heaton, J., 2002. Reworking qualitative data. Sage, London. 
Hesselbarth, C., Schaltegger, S., 2014. Educating change agents for sustainability - learning from the first sustainability management master of business administration. Journal of Cleaner production 62, 2436.

Hinds, P.S., Vogel, R.J., Clarke-Steffen, L., 1997. The Possibilities and Pitfalls of Doing a Secondary Analysis of a Qualitative Data Set. Quality Health Research 7 (3), 408-424.

Hodkinson, P., Issitt, M., 1995. The challenge of competence: Professionalism through vocational education and training. Cassell, London.

Lambrechts, W., Mulà, I., Ceulemans, K., Molderez, I., 2013. The integration of competences for sustainable development in higher education: an analysis of bachelor programs in management. Journal of Cleaner Production 48, 65-73.

Lans, T., Blok, V., Wesselink., R., 2014. Learning apart together: towards an integrated framework for sustainable entrepreneurship competence in higher education. Journal of Cleaner Production 62, 37-47.

Lievens, F., Sanchez, J.I., De Corte, W., 2004. Easing the inferential leap in competency modelling: the effects of task-related information and subject matter expertise. Personnel Psychology 57, 881-904.

Lozano, R., 2008. Envisioning sustainability three-dimensionally. Journal of Cleaner Production 16, $1838-1846$.

Lozano, R., 2012. Towards better embedding sustainability into companies' systems: an analysis of voluntary corporate initiatives. Journal of Cleaner Production 25, 14-26.

Maon F, Lindgreen, A, Swaen, V., 2009. Designing and implementing corporate social responsibility: an integrative framework grounded in theory and practice. Journal of Business Ethics 87, 71-89.

Marrewijk, M. van \& Werre, M., (2003). Multiple levels of corporate sustainability. Journal of Business Ethics 44, 107-119.

McLagan, P.A., 1989. Models for HRD Practice. The Models. American Society for Training and Development, Alexandria.

Mulder, M. (2014). Conceptions of professional competence. In: Billett, S., Harteis C., Gruber, H. (Eds). International Handbook on Research into professional and practice-based learning. Dordrecht: Springer.

Mulder, M., 2001. Competentie ontwikkeling in organisaties [Competence development in Organisations]. Elsevier Bedrijfsinformatie, Den Haag.

Mulder, M., Wesselink, R., Bruijstens, J. Chr. J., 2005. Job profile research for the purchasing profession. International Journal of Training and Development 9 (3), 185-204. 
Mogensen, F., Schnack, K., 2010. The action competence approach and the 'new' discourses of education for sustainable development, competence and quality criteria. Environmental Education Research 16 (1), 59-74.

Nidumolu, R., Prahalad, C.K., Rangaswami, M.R., 2009. Why Sustainability Is Now the Key Driver of Innovation. Harvard Business Review 87 (9), 56-64.

O’Riordan, L., Fairbrass, J., 2013. Managing CSR Stakeholder Engagement: A New Conceptual Framework. Journal of Business Ethics. DOI 10.1007/s10551-013-1913-x.

Peterson, C., 2009. Transformational supply chains and the 'wicked problem' of sustainability: Aligning knowledge, innovation, entrepreneurship, and leadership. Journal of Chain and Network Science 9, 7182.

Rieckmann, M., 2012. Future-oriented higher education: Which key competencies should be fostered through university teaching and learning. Futures 44, 127-135.

Rothaermel, F.T., Hess, A.M., 2007. Building Dynamic Capabilities: Innovation Driven by Individual-, Firm-, and Netwerk-Level effects. Organisation Science 18 (6), 898-921.

Sandberg, J., 2000. Understanding human competence at work: An interpretative approach. The Academy of Management Journal 43 (1), 9-25.

Schnack, K., 1996. Internationalisation, democracy and environmental education. In: Breiting, S., Nielsen, K. (Eds.) Environmental education research in the Nordic countries: proceedings from the research centre for environmental and health education. The Royal Danish School for Educational Studies, Copenhagen, pp 7-19.

Schwartz, B., Tilling, K., 2009. 'ISO-lating' Corporate Social Responsibility in the Organizational Context: A Dissenting Interpretation of ISO26000. Corporate Social Responsibility and Environmental Management 16, 289-299.

Selsky, J. W., Parker, B., 2005. Cross-Sector Partnerships to Address Social Issues: Challenges to Theory and Practice. Journal of Management 31, 849-873.

Smith, E., 2008. Pitfalls and Promises: The Use of Secondary Data Analysis in Educational Research. British Journal of Educational Studies 56 (3), 323-339.

Van Kleef, J.A.G., Room, N.J., 2007. Developing capabilities and competence for sustainable business management as innovation: a research agenda. Journal of Cleaner Production 15, 38-41.

Veldhuizen, M.T., Blok, V., Dentoni, D., 2013. Organisational Drivers of Capabilities for Multi-Stakeholder Dialogue and Knowledge Integration. Journal of Chain and Network Science (forthcoming). 
Wals, A.E.J., 2010. Mirroring, Gestaltswitching and transformative social learning: stepping stones for developing sustainable competence. International Journal of Sustainability in Higher Education Policy 15, $121-131$.

Wals, A.E.J., 2014. Sustainability in higher education in the context of the UN DESD: a review of learning and institutionalization processes. Journal of Cleaner Production 62, 8-15.

Wesselink, R., 2010. Comprehensive Competence-based education. Unpublished dissertation, Wageningen University.

Wiek, A., Withycombe, L., Redman, C.L., 2011. Key competencies in sustainability: a reference framework for academic program development. Sustainability Science 6, 203-218.

Willard, M., Wiedmeyer, C., Warren Flint, R., Weedon, J.S., Woodward, R., Feldman, I., Edwards, M., 2010. The sustainability professional: 2010 competency survey report. Environmental Quality Management. 49-83.

Wilson, A., Lenssen, G., Hind, P., 2006. Leadership Qualities and Management Competencies for Corporate Responsibility. Ashridge, United Kingdom.

Yin, R.K., 2009. Case study research: Design and methods, Volume 5. Sage, California. 
Appendix A Competencies and accompanying labels

\begin{tabular}{|c|c|}
\hline Competence & Labels \\
\hline $\begin{array}{l}\text { Systems thinking } \\
\text { (12 labels) }\end{array}$ & $\begin{array}{l}\text { 1. Analysing sub systems } \\
\text { 2. Analysing systems } \\
\text { 3. Cascading effects } \\
\text { 4. Causing effect relations } \\
\text { 5. Reflecting on elements of interdependency } \\
\text { 6. Identifying sub-systems } \\
\text { 7. Identifying scale } \\
\text { 8. Understanding aspects of interdependency } \\
\text { 9. Identifying systems } \\
\text { 10. Feedback loops } \\
\text { 11. Understanding scale effects } \\
\text { 12. Overview of motives }\end{array}$ \\
\hline $\begin{array}{l}\text { Foresighted thinking } \\
\text { (10 labels) }\end{array}$ & $\begin{array}{l}\text { 1. Crafting pictures of the future } \\
\text { 2. Assessing effects on intergenerational equity } \\
\text { 3. Balancing local \global } \\
\text { 4. Opportunities recognition } \\
\text { 5. Balancing long-term } \backslash \text { short-term } \\
\text { 6. Innovation } \\
\text { 7. Collectively evaluating pictures of the future } \\
\text { 8. Assessing unintended harmful consequences } \\
\text { 9. Collectively analysing pictures of the future } \\
\text { 10. Creativity }\end{array}$ \\
\hline $\begin{array}{l}\text { Normative competence } \\
\text { ( } 9 \text { labels) }\end{array}$ & $\begin{array}{l}\text { 1. Ethics } \\
\text { 2. Equity } \\
\text { 3. Inter and intra generational equity } \\
\text { 4. Principles } \\
\text { 5. Accountable for decision-making } \\
\text { 6. Values } \\
\text { 7. Sustainability values } \\
\text { 8. Justice } \\
\text { 9. Socio-ecological integrity }\end{array}$ \\
\hline $\begin{array}{l}\text { Embracing diversity and } \\
\text { Interdisciplinary } \\
\text { (7 labels) }\end{array}$ & $\begin{array}{l}\text { 1. Structure relations } \\
\text { 2. Facilitating dialogue } \\
\text { 3. Stimulating exchange of ideas } \\
\text { 4. Proactivity in information exchange } \\
\text { 5. Openness to other viewpoints } \\
\text { 6. Recognition of legitimacy of different viewpoints } \\
\text { 7. Involving stakeholders }\end{array}$ \\
\hline $\begin{array}{l}\text { Interpersonal } \\
\text { competence } \\
\text { (8 labels) }\end{array}$ & $\begin{array}{l}\text { 1. Enabling collaboration } \\
\text { 2. Communicating } \\
\text { 3. Facilitating collaboration } \\
\text { 4. Empathy }\end{array}$ \\
\hline
\end{tabular}




\begin{tabular}{|c|c|}
\hline & $\begin{array}{l}\text { 5. Ability to motivate collaboration } \\
\text { 6. Collaborating } \\
\text { 7. Compassion } \\
\text { 8. Negotiating }\end{array}$ \\
\hline $\begin{array}{l}\text { Action competence } \\
\text { ( } 5 \text { labels) }\end{array}$ & $\begin{array}{l}\text { 1. Proactive in decision making } \\
\text { 2. Taking responsibility } \\
\text { 3. Perseverance of goals } \\
\text { 4. Decision initiative } \\
\text { 5. Active involvement }\end{array}$ \\
\hline $\begin{array}{l}\text { Strategic management } \\
\text { (19 labels) }\end{array}$ & $\begin{array}{l}\text { 1. Evaluation of policies } \\
\text { 2. Controlling } \\
\text { 3. Collectively design interventions } \\
\text { 4. Leading } \\
\text { 5. Planning skills } \\
\text { 6. Taking action } \\
\text { 7. Inspiring } \\
\text { 8. Organize } \\
\text { 9. Implementing strategies } \\
\text { 10. Measuring performance } \\
\text { 11. Collectively implementing interventions } \\
\text { 12. Evaluation } \\
\text { 13. Arranging tasks } \\
\text { 14. Motivating } \\
\text { 15. Arranging resources } \\
\text { 16. Arranging people } \\
\text { 17. Designing transitions } \\
\text { 18. Evaluation of programs } \\
\text { 19. Evaluation of action plans }\end{array}$ \\
\hline
\end{tabular}

